\title{
A refinement of the emission data for Kola Peninsula based on inverse dispersion modelling
}

\author{
M. Prank ${ }^{1}$, M. Sofiev ${ }^{1}$, H. A. C. Denier van der Gon ${ }^{2}$, M. Kaasik ${ }^{3}$, T. M. Ruuskanen ${ }^{4}$, and J. Kukkonen ${ }^{1}$ \\ ${ }^{1}$ Finnish Meteorological Institute, P.O. Box 503, 00101 Helsinki, Finland \\ ${ }^{2}$ TNO, Princetonlaan 6, 3584 CB Utrecht, The Netherlands \\ ${ }^{3}$ University of Tartu, Ülikooli 18, 50090 Tartu, Estonia \\ ${ }^{4}$ University of Helsinki, Department of Physics, P.O. Box 68, 00014 Helsinki, Finland
}

Received: 31 May 2010 - Published in Atmos. Chem. Phys. Discuss.: 29 June 2010

Revised: 8 November 2010 - Accepted: 11 November 2010 - Published: 18 November 2010

\begin{abstract}
The study reviews the emission estimates of sulphur oxides $\left(\mathrm{SO}_{\mathrm{x}}\right)$ and primary particulate matter $(\mathrm{PM})$ from the major industrial sources of Kola Peninsula. Analysis of the disagreements between the existing emission inventories for the Kola region combined with forward and inverse ensemble dispersion modelling, analysis of observation time-series and model-measurement comparison showed that the emission of the Nikel metallurgy plant was missing or strongly under-estimated in the major European emission inventories, such as EMEP, EDGAR, TNO-GEMS, and PAREST-MEGAPOLI. In some cases it was misplaced or mis-attributed to other sources of the region. A more consistent inventory of the anthropogenic emissions of $\mathrm{SO}_{\mathrm{x}}$ and PM has been compiled for the Peninsula, compared with the existing estimates and verified by means of dispersion modelling. In particular, the SILAM model simulations for 2003 and 2006 with the revised emission data showed much smaller under-estimation of $\mathrm{SO}_{2}$ concentrations at 8 Finnish and Norwegian observational stations. For the nearest site to the plant the 10-fold underestimation turned to a 1.5 -fold over-prediction. Temporal correlation improved more moderately (up to $45 \%$ for concentrations, up to 3 times for deposition). The study demonstrates the value of a combined usage of forward and inverse ensemble modelling for source apportionment in case of limited observational data.
\end{abstract}

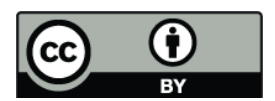

Correspondence to: M. Prank (marje.prank@fmi.fi)

\section{Introduction}

The emission database of EMEP (Co-operative Programme for Monitoring and Evaluation of the Long-range Transmission of Air Pollutants in Europe, http://www.emep.int) (UNECE, 2009) includes anthropogenic emissions and some natural sources (volcanoes in Italy and DMS marine fluxes), with yearly time step and ca. $50 \mathrm{~km}$ spatial resolution. The emission inventory is based on the reports of the European countries and the estimations of EMEP experts. The EMEP database is one of the main sources of information for atmospheric dispersion modelling in Europe and contains one of the best-verified datasets.

Other emission inventories covering Europe, such as GEIA (http://www.geiacenter.org), CGEIC (http://www. ortech.ca/cgeic), RETRO (http://retro.enes.org), EDGAR (http://www.mnp.nl/edgar), TNO-GEMS (Visschedijk et al., 2007) and PAREST-MEGAPOLI (Denier van der Gon et al., 2010), are partly independent from the EMEP database but still maintain some of its features.

These databases contain comprehensive information about European emissions but in some cases additional efforts are needed to improve the quality. In particular, several atmospheric dispersion simulations have shown that pollutant concentrations in Lapland are usually underestimated with respect to measurements at the monitoring stations in Finland, Sweden and Norway, unless extra information is included (Hongisto et al., 2003; Bartnicki et al., 2002, 2004, 2006; Zlatev et al., 2001; Sofiev et al., 1994, 2003; Sofiev, 2000; BACC, 2008, and also the EMEP own simulations, e.g. EMEP, 2007, 2008, 2009). As shown below, one of the reasons for that is the deficiency of emission information for the Kola Peninsula. 
An emerging approach to refine emission data is inverse atmospheric dispersion modelling. It has become a useful tool in model-based analysis of observations and source apportionment studies (e.g. Kuparinen et al., 2007; Rannik et al., 2003; Bergamaschi et al., 2005; Saarikoski et al., 2007; Sofiev et al., 2006a; Elbern et al., 1997, 1999, 2007). The method can be used for both correcting the emission rates of known sources and delineating the origins of observed concentration peaks. Source apportionment using dispersion models is a corner stone of the nuclear emergency preparedness activity (Bocquet, 2005a,b; Issartel, 2005; Issartel and Baverel, 2003; Thomson et al., 2007; Loosmore et al., 2007; Chang et al., 1997 etc.).

The specific approach to the source apportionment depends on abundance and coverage of available observational information, modelling tools and a-priori information on the sources. If measurement data are available from sufficiently dense network with sufficiently high time resolution, a fullscale data assimilation problem can be solved with the emission rate and/or its distribution being the assimilated quantities. However, the requirements to the observational data are very stringent in this case. Additionally, only advanced and expensive methodologies, such as the four-dimensional variational assimilation (4-D-VAR) or the ensemble Kalman filtering allow explicit emission treatment (Elbern et al., 2007).

When the source pattern is simple and the observational data are scarce, certain reductions of the methodology are possible or even inevitable. In an extreme case, a crude analysis can be based on trivial backward trajectories. Interpretation of such results is usually qualitative (e.g. Barletta et al., 2009; Skjøth et al., 2007), but sometimes quantitative analysis can be undertaken (Kulmala, 2000; Sogacheva et al., 2005, 2007; Heo et al., 2009). For quantitative and comparatively accurate assessment in case of limited observational information, the so-called "footprint" computations can be used (Rannik et al., 2003; Kuparinen et al., 2007; Saarikoski et al., 2007). This approach is based on solving the adjoint dispersion equation for e.g. an isolated episode registered by a single measurement device. The result of the adjoint computations describes the sensitivity distribution of that particular measurement. The observed values are sensitive to the emission fluxes from the area where the sensitivity is nonzero. This area is referred as the measurement footprint.

In Lapland the source apportionment problem has to be based on a limited set of stations, but fortunately the region has just a few almost-point sources dominating the emission pattern. Such distribution simplifies the source location problem, but also leads to a high sensitivity of the refined emission estimates to the uncertainties of the meteorological and dispersion models. For instance, a limited deviation of the predicted wind direction from the actual one may result in the model plume missing the particular station, thus jeopardizing the model-measurement comparison.

The uncertainties of the individual simulations can be reduced by constructing a modelling ensemble. This tool has proven to be useful for various tasks, including air quality analysis and forecasting (http://gems.ecmwf.int, http:// www.gmes-atmosphere.eu, Sofiev et al., 1996; http://www. gse-promote.org, Delle Monache and Stull, 2003; Mallet and Sportisse, 2006; Pagowski and Grell, 2006) and also emergency modelling with point-type sources (Galmarini et al., 2004a,b; Potempski et al., 2008), i.e. for the emission distributions similar to the current study. It has been shown that even a simple arithmetical average, or the median as its robust analogy, of the individual ensemble members (airquality models or specific simulations) usually shows better scores in the model-measurement comparisons than any single participating model (Galmarini et al., 2004c; Riccio et al., 2007; Potempski et al., 2008). The spread between the individual models then indicates the predictability of the episode, its stochastic features, and the potential range of the uncertainties in the results of the simulations. More sophisticated approaches are under construction, aiming at the optimal selection and combination of the ensemble members and at softening or lifting some of the underlying assumptions concerning the relation between the ensemble and the actual probability distribution (Galmarini et al., 2004c; Mallet and Sportisse, 2006; Riccio et al., 2007; Delle Monache et al., 2006).

The goals of the current paper are to (i) demonstrate the methodology of source apportionment suitable for the case of limited observational information and highly variable pollution patterns; (ii) refine the estimates of emission and distribution of sulphur oxides $\left(\mathrm{SO}_{2}\right.$ and $\left.\mathrm{SO}_{4}^{2-}\right)$ and particulate matter (PM) in Northern Lapland caused by the industrial sources of Kola Peninsula. The study includes the following steps: (i) the analysis of the emission patterns of Kola Peninsula in the existing emission inventories, (ii) the emission sector based refinement of the emission data taking the EMEP inventory as a starting point, (iii) the verification of the proposed adjustments using ensemble forward and adjoint dispersion simulations with the SILAM modelling system, and (iv) the evaluation of the impact of the emission refinement on the predicted air pollution of the region.

\section{Analyses and refinement of the emission distribution of Kola Peninsula}

The industrial pattern of Kola Peninsula is heavily dominated by three major centres of activity (Fig. 1): the Nikel $\left(69^{\circ} 20^{\prime} \mathrm{N}, 30^{\circ} 04^{\prime} \mathrm{E}\right)$ and Monchegorsk ( $\left.67^{\circ} 55^{\prime} \mathrm{N}, 32^{\circ} 57^{\prime} \mathrm{E}\right)$ non-ferrous metallurgy plants and mines, and the city of Murmansk $\left(68^{\circ} 57^{\prime} \mathrm{N}, 33^{\circ} 06^{\prime} \mathrm{E}\right)$ with the nearby harbour. There is very limited anthropogenic activity outside these centres.

The $\mathrm{SO}_{\mathrm{x}}$ emissions from Nikel and Monchegorsk plants are by far the largest in the region, roughly twice larger than that of the whole Finland (Ahonen et al., 1997). The Monchegorsk and Murmansk city emissions are also rich in 


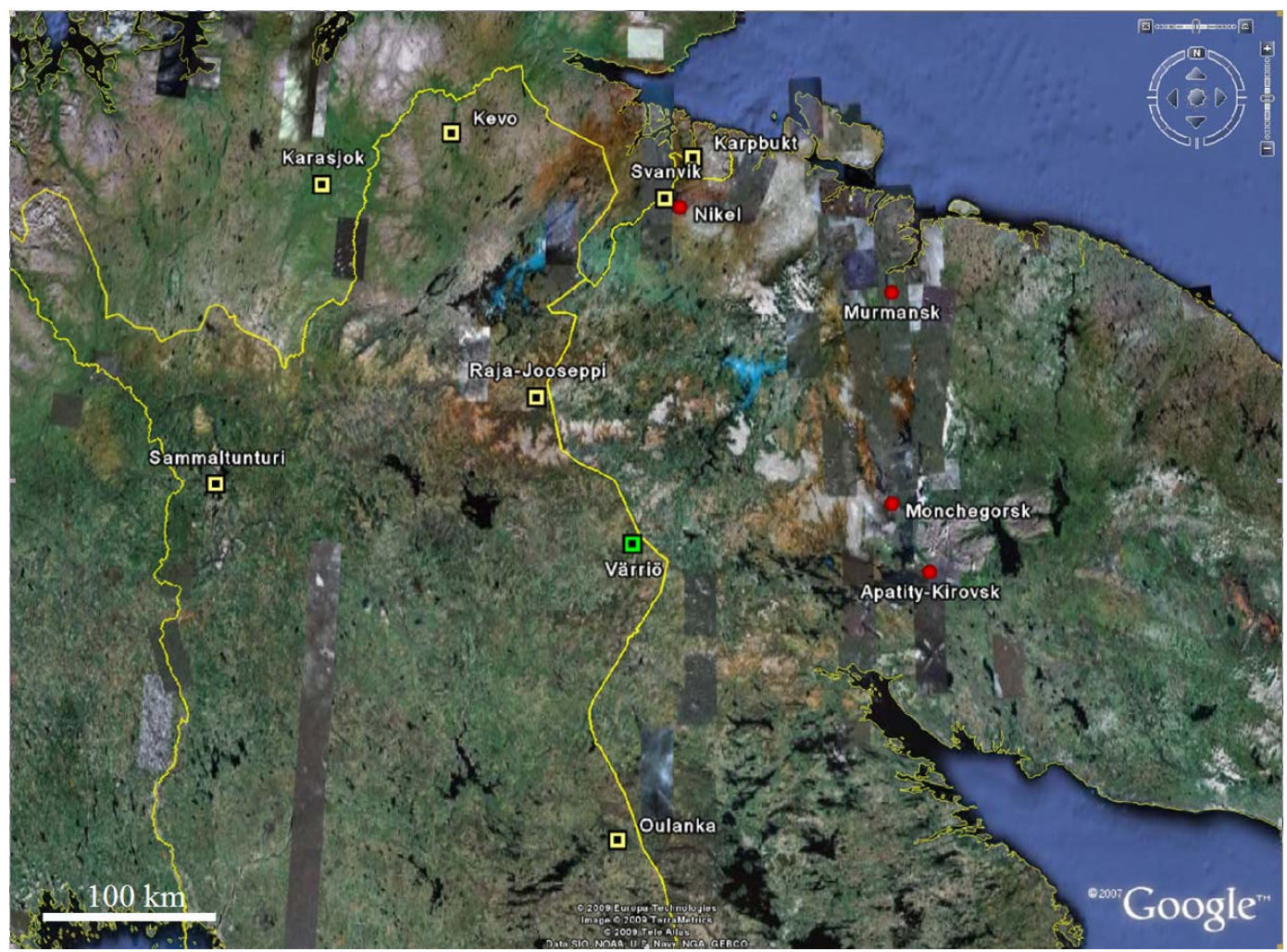

Fig. 1. Location of the major pollution sources of Kola Peninsula (red circles), the Varrio measurement station (green rectangle) and the other measurement sites (yellow rectangles).

$\mathrm{NO}_{\mathrm{x}}$, contrary to those of the Nikel plant, which has high $\mathrm{SO}_{\mathrm{x}}$ but low $\mathrm{NO}_{\mathrm{x}}$ fraction (Ruuskanen et al., 2003; Virkkula et al., 2003). The PM emissions from these three sources are comparable but uncertainties are large, also due to relatively high contribution of other sources. The PM non-industrial contributions are dispersed and originate from very different sources: road dust, sea salt, production of secondary aerosols, etc. The natural $\mathrm{NO}_{\mathrm{x}}$ emissions around Lapland are very small and $\mathrm{NO}_{\mathrm{x}}$ background concentration is caused by long range transport from Central and Eastern Europe ( $\mathrm{Ru}-$ uskanen et al., 2003; Virkkula et al., 2003). The natural $\mathrm{SO}_{\mathrm{x}}$ in Lapland originate from marine DMS production, which forms a generally low background level (Ruuskanen et al., 2003; Tarrasson et al., 1995).

The best-articulated tracer for the industrial emission distribution in Lapland and Kola region is $\mathrm{SO}_{2}$, which is also monitored by most of the observational stations of the region. The available information on other species is scarcer. Therefore, below we concentrate on the $\mathrm{SO}_{\mathrm{x}}$ emission and project its emission sector specific modifications to particulate emission.

\subsection{Evaluation of EMEP $\mathrm{SO}_{2}$ emission data}

The currently available EMEP data for Kola Peninsula reports strongly varying emission amounts and patterns for different years (see Table 1 and Fig. 2). These inconsistencies can be traced back to the evolution of the database. According to the EMEP rules, every five years the emission distributions must be updated and reported afresh to the database by the member states. For intermittent years only the national totals are reported while the patterns are assumed to be fixed and just scaled appropriately. Upon the decision of the member states, the data can be revised retrospectively.

Until the early 1990s, the EMEP standard grid resolution was $150 \mathrm{~km}$. In this grid the locations of Murmansk and the Nikel plant belonged to two neighbouring grid-cells. For the year 1992 (the last available with $150 \mathrm{~km}$ resolution), over $250 \mathrm{kTon} \mathrm{yr}^{-1}$ of $\mathrm{SO}_{2}$ emission was reported in the grid-cell

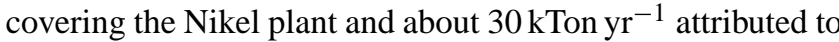
Murmansk grid-cell (Sofiev, 2000).

In mid-1990s the default resolution of EMEP emission database was changed to $50 \times 50 \mathrm{~km}$ and the emissions were recomputed retrospectively. That resulted in abrupt rearrangement of the emission pattern of Kola Peninsula. A strong source of $\mathrm{SO}_{\mathrm{x}}$ was shown for 1980 in the grid-cell (48, 91) neighbouring Murmansk and for 1985 in the grid-cell 
Table 1. The EMEP $\mathrm{SO}_{\mathrm{x}}$ emission data for Kola Peninsula. (Unit: tons of $\mathrm{SO}_{2}$ per grid cell per year.)

\begin{tabular}{|c|c|c|c|c|c|c|c|c|c|c|c|c|c|c|c|}
\hline \multicolumn{2}{|c|}{ Gridcell } & Lon & Lat & 1980 & 1985 & 1990 & 1992 & 1995 & 2000 & 2003 & 2005 & 2007 & original & corrected & $1992(150 \times 150)$ \\
\hline 46 & 90 & 30.3 & 69.5 & 1606 & 588 & 86 & 66 & 37 & 29 & 21 & 7009 & 5551 & 438 & 110085 & \\
\hline 47 & 90 & 30.8 & 69.1 & 3113 & 480238 & 162 & 125 & 69 & 54 & 41 & 35 & 42 & 849 & 849 & \\
\hline 48 & 91 & 32.6 & 68.9 & 421398 & 1072 & 27815 & 22347 & 14146 & 10179 & 9013 & 1619 & 781 & 114916 & 39121 & \\
\hline 48 & 92 & 33.8 & 69.1 & 125016 & 17422 & 6214 & 4787 & 2646 & 2043 & 1560 & 1370 & 1118 & 34092 & 240 & \\
\hline 48 & 93 & 35.0 & 69.3 & 18638 & 535 & 861 & 662 & 363 & 274 & 218 & 195 & 97 & 5083 & 5083 & \\
\hline 49 & 91 & 33.1 & 68.5 & 3455 & 88479 & 187 & 145 & 81 & 64 & 47 & 40 & 52 & 942 & 942 & \\
\hline 50 & 88 & 30.4 & 67.4 & 5186 & 19252 & 269 & 208 & 115 & 90 & 67 & 59 & 71 & 1414 & 1414 & \\
\hline 50 & 90 & 32.5 & 67.9 & 16811 & 1072 & 869 & 670 & 372 & 290 & 217 & 189 & 225 & 4584 & 4584 & \\
\hline 50 & 91 & 33.7 & 68.0 & 12280 & 17107 & 652 & 503 & 280 & 220 & 163 & 141 & 180 & 3349 & 3349 & \\
\hline 51 & 89 & 32.0 & 67.2 & 17562 & 20773 & 1130 & 902 & 560 & 410 & 352 & 331 & 286 & 4789 & 4789 & \\
\hline 51 & 90 & 33.1 & 67.4 & 299846 & 196543 & 23148 & 18829 & 12350 & 8846 & 7943 & 7660 & 6163 & 81769 & 81769 & \\
\hline 51 & 91 & 34.2 & 67.6 & 88199 & 1072 & 6747 & 5482 & 3586 & 2572 & 2303 & 2218 & 1794 & 24052 & 24052 & \\
\hline \multicolumn{4}{|c|}{ Total of Peninsula } & 1070305 & 863490 & 71009 & 56937 & 35829 & 26019 & 22667 & 21496 & 17007 & 291875 & 291875 & 507800 \\
\hline \multicolumn{16}{|c|}{$150 \mathrm{~km}$ grid cells, aggregate from $50 \mathrm{~km}$ and the old dataset } \\
\hline $46-48$ & $88-90$ & 29.7 & 68.9 & 17900 & 486608 & 925 & 714 & 396 & 310 & 232 & 7192 & 5765 & 4881 & 114529 & 253100 \\
\hline $46-48$ & $91-93$ & 33.2 & 69.5 & 675634 & 21273 & 35411 & 28197 & 17376 & 12665 & 10922 & 3299 & 2096 & 156977 & 47329 & 29800 \\
\hline $49-51$ & $88-90$ & 31.5 & 67.7 & 361125 & 242517 & 26545 & 21479 & 13881 & 10015 & 8862 & 8484 & 7041 & 98480 & 98480 & 193500 \\
\hline $49-51$ & $91-93$ & 34.9 & 68.2 & 115647 & 113091 & 8128 & 6547 & 4175 & 3029 & 2650 & 2522 & 2522 & 2104 & 31537 & 31400 \\
\hline \multicolumn{16}{|c|}{ ontribution of the main sources, $\%$} \\
\hline \multicolumn{4}{|c|}{ Nikel \% } & 2 & 56 & 1 & 1 & 1 & 1 & 1 & 33 & 34 & 2 & 39 & 50 \\
\hline \multicolumn{4}{|c|}{ Murmansk \% } & 54 & 2 & 50 & 50 & 48 & 49 & 48 & 15 & 12 & 54 & 16 & 6 \\
\hline \multicolumn{4}{|c|}{ Monchegorsk etc \% } & 45 & 41 & 49 & 49 & 50 & 50 & 51 & 51 & 54 & 45 & 45 & 44 \\
\hline
\end{tabular}

Presented data in:

individual years: EMEP web emission portal WebDab, status 2010,

original: the prior-2006 WebDab download for 2000,

corrected: the outcome of this work,

$1992150 \mathrm{~km} \times 150 \mathrm{~km}$ : the old $150 \mathrm{~km}$ dataset. Highlithed grid cells: green - Nikel, red - Murmansk, yellow - Monchegorsk and its surroundings.

The values from 1990-2007 mark the data recomputed after 2006.

$(47,90)$ neighbouring the Nikel plant location (Table 1 and Fig. 2). However, the plant itself was not represented as a source. The total emission of the Kola Peninsula stayed at similar level as in the $150 \times 150 \mathrm{~km}$ resolving dataset. Until 2006, emission data with similar regional totals and patterns were available from EMEP for 1990s and beginning of 2000s.

In 2006 all emissions of Kola Peninsula starting from 1990 were recomputed following the latest reported data (EMEP, 2006) and appear more than an order of magnitude lower than the previous estimate and with a new distribution pattern (Table 1 and Fig. 2). For 2005, for the first time for the $50 \mathrm{~km}$ resolving dataset, somewhat higher emissions (compared to surrounding background level) show up in the grid cell $(46,90)$ containing the Nikel plant. However, the emission of that grid cell is still too low.

The changes of 2006 have not affected the projections for 2010 and 2020, which thus stayed at the previously reported levels and patterns.

The same problems are evident for other substances, such as $\mathrm{NO}_{\mathrm{x}}$ (to smaller extent and with somewhat different temporal pattern). The totals for other regions of Russia located within the EMEP domain do not exhibit such abrupt changes.

For the following analysis we consider the problems of regional totals and the distribution patterns separately.
Considering the sharp changes since 1980s reported by Russia in the presently available version of the EMEP database, one should take into account that the decline of the economy of the region in 1980s-1990s may indeed result in some decrease of the emission. However, we are not aware of any dedicated large-scale emission-reduction measures at the plant. Boyd et al. (2009) cautiously mentioned $\sim 33 \%$ reduction during 1990s with a reference to the official values and assumed no modernisation of the plant. According to Hagen et al., (2002) and Berglen et al. (2008), the $\mathrm{SO}_{2}$ emissions of the Nikel plant were reported around 250-300 $\mathrm{kTon} \mathrm{yr}^{-1}$ until mid-1980s and reduced to $\sim 175 \mathrm{kTon} \mathrm{yr}^{-1}$ by the beginning of 1990s. After that no significant long-term trend is reported but the data are scarce after 1993. Ahonen et al. (1997), referring to Baklanov (1994) and to Committee (1995) report, suggests the $\mathrm{SO}_{2}$ emissions of the whole

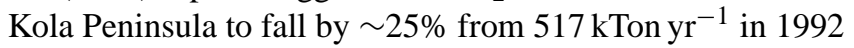

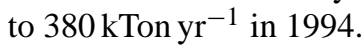

The $\mathrm{SO}_{2}$ concentration measurements in surrounding stations also do not support the changes shown by present EMEP data. The Svanvik measurement station in Norway reports about 2 times reduction in $\mathrm{SO}_{2}$ annual mean concentrations from the late 1980's to beginning of 1990s (Hagen et al., 2002; Berglen et al., 2008). No significant change in $\mathrm{SO}_{2}$ has been observed at Svanvik, Maajavri, Nikel, Viksjøfjell 


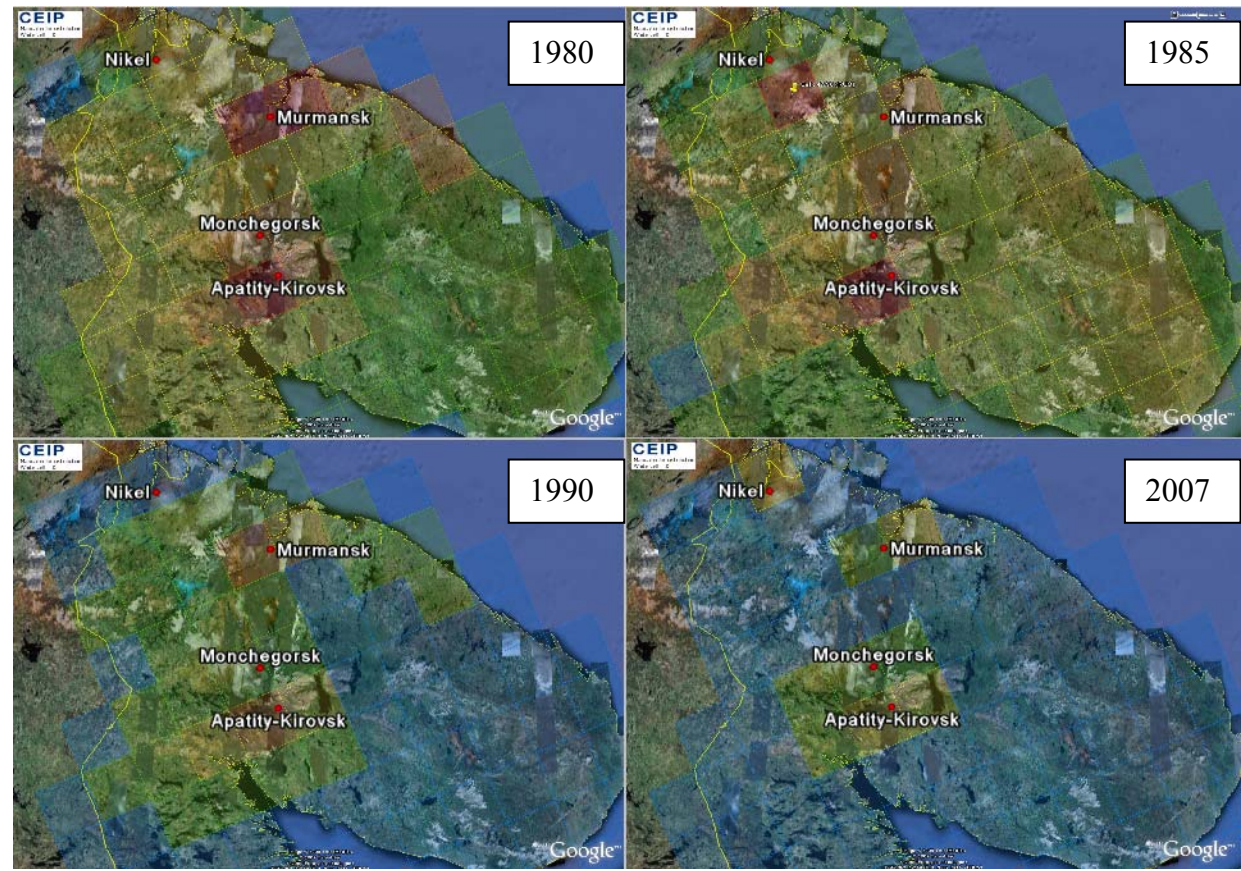

Fig. 2. The original EMEP emission for 1980-2007, WebDab status 2010. The 50km grid cells are shown with the colours reflecting the $\mathrm{SO}_{\mathrm{x}}$ emission: blue $<=0.1 \mathrm{kTon} \mathrm{yr}^{-1} \mathrm{SO}_{2}$, green $<=1 \mathrm{kTon} \mathrm{yr}^{-1} \mathrm{SO}_{2}$, yellow $<=10 \mathrm{kTon} \mathrm{yr}^{-1} \mathrm{SO}_{2}$, orange $<=100 \mathrm{kTon} \mathrm{yr}^{-1} \mathrm{SO}_{2}$,

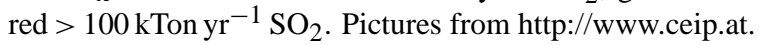

or Varrio stations in 1990s and 2000s (Hagen et al., 2002; Berglen et al., 2008; Ruuskanen et al., 2003; Virkkula et al., 2003). EMEP stations in Lapland also reported only gradual trends without any drastic changes during the last 20 years. In particular, there was no dramatic decrease of the upper percentiles of the daily mean concentrations observed by any EMEP station of the region (Fig. 3).

Therefore, the sharp fall of all emissions over Kola Peninsula and large random changes in the emission distribution do not seem justified. Since the period of the fastest economical decline had ended by the mid-90s, the reported total emission of 1992 should not be too far from the emissions of later years, at least until 2008, when the current crisis started.

\subsection{Comparison of the emission inventories}

There are numerous inventories of anthropogenic emission, covering various regions and time periods with different spatial and temporal resolutions and containing different sets of pollutant species (Table 2). For Europe, the most extensive databases, with the largest number of pollutants and the highest spatial and temporal resolutions are EMEP, TNOGEMS and PAREST-MEGAPOLI, and RETRO. The global databases, such as GEIA, EDGAR and CGEIC usually have low $\left(1 \times 1^{\circ}\right)$ resolution, which is insufficient for regional model applications. However, they can still be considered for comparison when it comes to regional totals.

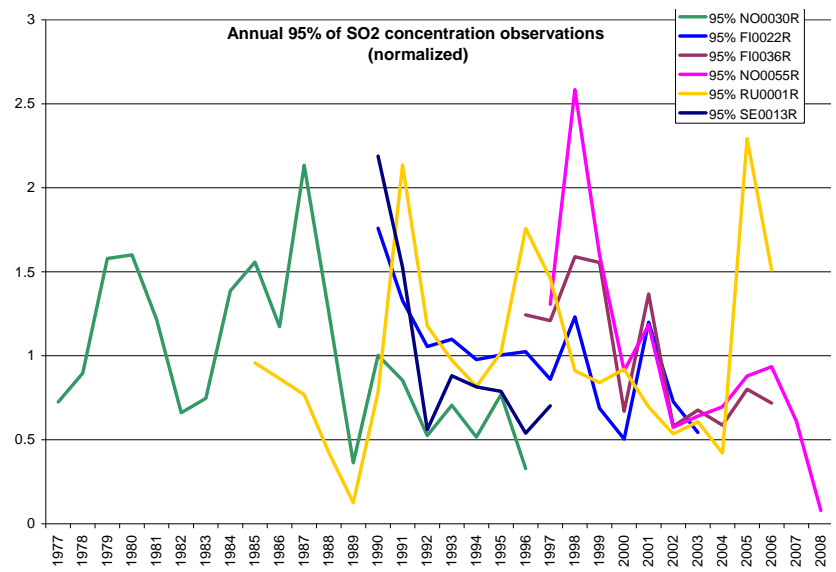

Fig. 3. Time series of the 95th percentile of the measurements of $\mathrm{SO}_{2}$ concentration in air by the stations near Nikel, normalised to unit average.

In the TNO-GEMS inventory for 2003, the initial EMEP emission distributions have been significantly rearranged but the national totals for most countries are based on values reported to EMEP. Independent bottom-up assessment from activity data and emission factors were used only if the reported data were missing or suspected to be erroneous. In particular, new emissions were generated for Russian Federation, including Kola peninsula (Visschedijk et al., 2007). 
The total $\mathrm{SO}_{2}$ emission of the region is assessed to be around $140 \mathrm{kTon} \mathrm{yr}^{-1}$ of $\mathrm{SO}_{2}$, which is of the same order of magnitude, though lower than the regional total of EMEP 1992 with $150 \mathrm{~km}$ grid resolution (Table 1). The emission distribution for $\mathrm{SO}_{2}$ in the TNO-GEMS inventory differs considerably from that of EMEP and explicitly shows Nikel plant emission. However, it attributes about $80 \%$ of the emissions of the Peninsula to the Monchegorsk area and only about

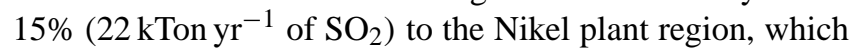
is doubtful. For instance, Boyd et al. (2009) mentioned $300 \mathrm{kTon} \mathrm{yr}^{-1}$ (with a reference to Zientek et al., 1994) as a total-Kola industrial $\mathrm{SO}_{2}$ emission with $\sim 70 \%$ attributed to the Nikel plant region.

The step from TNO-GEMS to PAREST-MEGAPOLI included a complete overhaul of the European point source database including removal of the closed installations and expansion with all new point sources accessible through source-sector specific databases or statistics. There were two major reasons for this. Firstly, it improved the completeness of the list of European point sources. Secondly, for Russia the assessment relied on the estimates of the national sector total emissions by the IIASA RAINS/GAINS model (http://gains.iiasa.ac.at) which was adjusted significantly after releasing the TNO-GEMS database. The reconsideration of the point sources and Russian emission totals resulted in almost doubling the total $\mathrm{SO}_{2}$ emission of the point sources in Kola Peninsula: from 170 to $266{\mathrm{kTon} \mathrm{yr}^{-1}}^{-1}$ of $\mathrm{SO}_{2}$ (Fig. 4). However, the emission distribution still at-

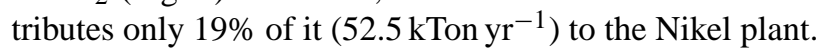

The RETRO database does not provide anthropogenic $\mathrm{SO}_{\mathrm{x}}$ emissions. For other pollutants, the RETRO emission assessments are independent from EMEP but still based on a similar set of activity data (energy statistics) and share most of its features concerning, in particular, the spatial distribution.

The EDGAR emission data are available only for years 1990 and 1995. The total levels are comparable with EMEP $1992150 \mathrm{~km}$ resolution emissions, dropping by a factor of 1.7 between these years. However, the emission pattern still does not show any significant emissions at the Nikel plant location, and has an unrealistically large source in the Murmansk area (Table 3).

GEIA and CGEIC emissions for Europe are based on either EMEP or EDGAR assessments.

Concluding the analysis, none of the considered inventories contains information which would simultaneously have (i) sufficient resolution, (ii) correct distribution of the major sources, (iii) reasonable absolute emission level. Below we have compiled a dataset which seems to be matching these criteria better than the existing inventories.

\subsection{Starting point for the emission correction}

Selecting the initial dataset for modifications, we took into account that the previous modelling activities (Saarikoski et al., 2007; Galperin et al., 1994a,b; Sofiev et al., 1995;
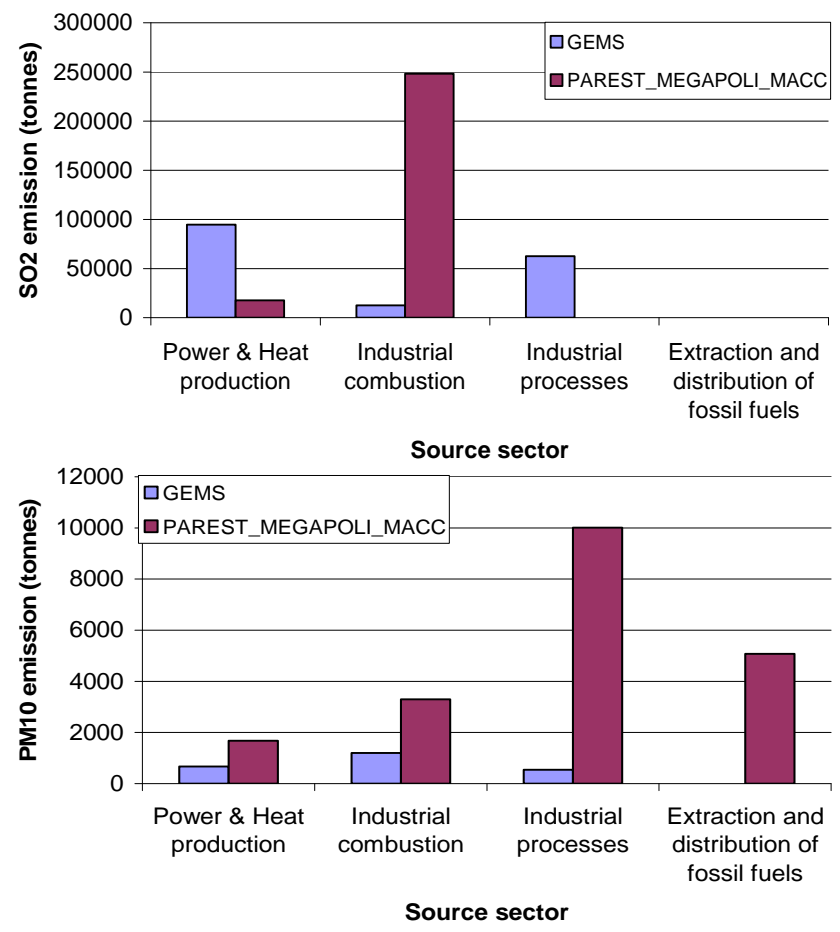

Fig. 4. Emissions of $\mathrm{SO}_{2}$ (upper panel) and $\mathrm{PM}_{10}$ (lower panel) for the Kola domain in TNO-GEMS and PAREST-MEGAPOLI databases.

Galperin and Sofiev, 1998; Sofiev, 2000; EMEP assessment reports prior to 2006, http://www.emep.int) have not shown significant over-estimation of $\mathrm{SO}_{\mathrm{x}}$ and $\mathrm{PM}$ concentrations in 1990s and 2000s, when the data with absolute levels similar to those of the EMEP $150 \mathrm{~km}$ emissions for 1992 are used. Secondly, the EMEP datasets until mid-2000s reported $\sim 40 \%$ reduction from these levels (e.g. EMEP, 1999, 2000), which is similar to the reduction reported by Ahonen et al. (1997), Boyd et al. (2009) and Zientek et al. (1994). Therefore, we assumed that the total emission for the Peninsula in 1990s and first half of 2000s is close to

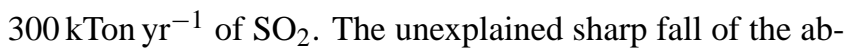
solute level of emissions (by a factor of 15-20) in the later EMEP reports was considered to be unjustified and disregarded.

The datasets with the Kola emission totals close to $300 \mathrm{kTon} \mathrm{yr}^{-1}$ of $\mathrm{SO}_{2}$ and $50 \mathrm{~km}$ resolution could be downloaded from the EMEP WebDab portal before 2006. They have only one evident error in the distribution: entirely missing Nikel plant emission. The next task of this work is, therefore, to correct this error. The emission data for year 2003, downloaded before 2006 was chosen as the reference point for the correction (Table 1). The dataset misses the Nikel plant emissions, while an extremely strong source of $\mathrm{SO}_{2}$ (about $150 \mathrm{kTon} \mathrm{yr}^{-1}$ of $\mathrm{SO}_{2}$ ), $\mathrm{NO}_{\mathrm{x}}, \mathrm{CO}$ and $\mathrm{PM}$ is placed around Murmansk. A large fraction of the emission there is reported for the SNAP sector 1, (Large combustion in 
Table 2. The summary of the databases for anthropogenic emissions in Europe.

\begin{tabular}{|c|c|c|c|c|}
\hline Database & $\begin{array}{l}\text { Anthropogenic emission } \\
\text { species }\end{array}$ & Resolution & $\begin{array}{l}\text { Time resolution; } \\
\text { Available times }\end{array}$ & Data source for European emissions \\
\hline $\begin{array}{l}\text { EMEP } \\
\text { WebDaB }\end{array}$ & $\begin{array}{l}\mathrm{SO}_{\mathrm{x}}, \mathrm{NO}_{\mathrm{x}}, \mathrm{NMVOC}, \mathrm{NH}_{3}, \mathrm{PM}_{10} \\
\mathrm{PM}_{2.5}, \mathrm{PMcoarse}, \mathrm{CO}, \mathrm{POPs}, \mathrm{HMs}\end{array}$ & $\begin{array}{l}50 \times 50 \mathrm{~km}^{2} \\
150 \times 150 \mathrm{~km}^{2}\end{array}$ & $\begin{array}{l}\text { Annual, with diurnal, } \\
\text { weekly and monthly } \\
\text { variations } \\
1980,1985,1990 \text {, } \\
1995-2007 \text { and } 2010 \text {, } \\
2020\end{array}$ & $\begin{array}{l}\text { http://www.emep.int } \\
\text { http://www.ceip.at/emission-data-webdab/ } \\
\text { Emissions reported by the countries }\end{array}$ \\
\hline EDGAR & $\begin{array}{l}\mathrm{NO}_{\mathrm{x}}, \mathrm{NMVOC}, \mathrm{SO}_{2}, \mathrm{HCs} \\
\mathrm{CO}_{2}, \mathrm{CH}_{4}, \mathrm{~N}_{2} \mathrm{O}, \mathrm{CO}, \text { halocarbons }\end{array}$ & $1^{\circ} \times 1^{\circ}$ & $\begin{array}{l}\text { Annual } \\
1990,1995\end{array}$ & $\begin{array}{l}\text { http://www.mnp.nl/edgar/documentation/methodology/ } \\
\text { bottom-up inventory based on activity data and emission factors }\end{array}$ \\
\hline GEIA & $\begin{array}{l}\mathrm{NH}_{3}, \mathrm{Black} \text { Carbon, } \mathrm{NO}_{\mathrm{x}}, \mathrm{SO}_{2}, \\
\mathrm{NMVOC}, \mathrm{CO}_{2}, \mathrm{CO}, \mathrm{CFCs}, \mathrm{HCFC}-22, \\
\mathrm{MCF}, \mathrm{Pb}, \mathrm{Hg}, \mathrm{CH}_{4}, \mathrm{~N}_{2} \mathrm{O}, \text { Pesticides, } \\
\text { Reactive } \mathrm{Cl}\end{array}$ & $1^{\circ} \times 1^{\circ}$ & $\begin{array}{l}\text { Annual, Seasonal } \\
1985\end{array}$ & $\begin{array}{l}\text { http://www.geiacenter.org/ } \\
\text { Emissions for western Europe taken from CORINAIR; the } \\
\text { EMEP inventories for European areas not covered by } \\
\text { CORINAIR. }\end{array}$ \\
\hline CGEIC & $\mathrm{SO}_{2}, \mathrm{NO}_{\mathrm{x}}, \mathrm{Pb}, \mathrm{HCH}, \mathrm{Hg}$ & $1^{\circ} \times 1^{\circ}$ & $\begin{array}{l}\text { Annual, seasonal } \\
1985\end{array}$ & $\begin{array}{l}\text { http://www.ortech.ca/cgeic/poster.html } \\
\text { GEIA, EDGAR GEIA 1A, annual sulphur and nitrogen global } \\
\text { emission inventory }\end{array}$ \\
\hline RETRO & $\mathrm{NO}_{\mathrm{x}}, \mathrm{VOCs}, \mathrm{CO}$ & $0.5^{\circ} \times 0.5^{\circ}$ & $\begin{array}{l}\text { Annual, monthly mean } \\
1960-2000 ?\end{array}$ & $\begin{array}{l}\text { http://retro.enes.org/reports/D1-6_final.pdf } \\
\text { Bottom-up inventory based on activity data and emission factors } \\
\text { of TNO Emission Assessment Model (TEAM) }\end{array}$ \\
\hline $\begin{array}{l}\text { TNO-GEMS } \\
\text { and } \\
\text { PAREST- } \\
\text { MEGAPOLI }\end{array}$ & $\begin{array}{l}\mathrm{NO}_{\mathrm{x}}, \mathrm{SO}_{2}, \mathrm{CO}, \mathrm{NMVOC}, \mathrm{CH}_{4}, \mathrm{NH}_{3} \\
\mathrm{PM}_{10}, \mathrm{PM}_{2.5}\end{array}$ & $0.25^{\circ} \times 0.125^{\circ}$ & $\begin{array}{l}\text { Monthly } \\
2003 \\
2005\end{array}$ & $\begin{array}{l}\text { National and sector totals reported by the countries. IIASA } \\
\text { RAINS/GAINS if reported values not available or suspicious } \\
\text { (e.g. for Russian territory). }\end{array}$ \\
\hline
\end{tabular}

Table 3. EDGAR $\mathrm{SO}_{2}$ emissions (Unit: tons of $\mathrm{SO}_{2} \mathrm{yr}^{-1}$ ). Grid cells containing the largest sources have been highlighted (green Nikel, red - Murmansk, yellow - Monchegorsk).

\begin{tabular}{lrrrrrrrr}
\hline \multicolumn{7}{c}{ Emissions of year 1990 } \\
\hline lat/lon & 28 & 59 & 30 & 31 & 32 & 33 & 34 & 35 \\
\hline 70 & 890 & 983 & 0 & 0 & 0 & 0 & 0 & 0 \\
69 & 151 & 1850 & 4440 & 377000 & 0 & 0 & 0 & 0 \\
68 & 179 & 0 & 0 & 39 & 1260 & 61300 & 42 & 65 \\
67 & 1430 & 647 & 2470 & 39 & 13400 & 11300 & 196 & 0 \\
66 & 1030 & 301 & 7 & 52 & 209 & 196 & 120 & 0 \\
\hline \multicolumn{7}{c}{ Total: 481396 ton $\mathrm{SO}_{2} / \mathrm{yr}$} \\
\hline \multicolumn{7}{c}{ Emissions for year 1995} \\
\hline lat/lon & 28 & 59 & 30 & 31 & 32 & 33 & 34 & 35 \\
\hline 70 & 719 & 749 & 0 & 0 & 0 & 0 & 0 & 0 \\
69 & 169 & 1040 & 2480 & 227000 & 0 & 0 & 0 & 0 \\
68 & 188 & 0 & 0 & 40 & 716 & 33700 & 41 & 66 \\
67 & 1190 & 556 & 1380 & 40 & 7300 & 6180 & 199 & 0 \\
66 & 870 & 339 & 7 & 53 & 212 & 199 & 122 & 0 \\
\hline \multicolumn{7}{c}{ Total: 285600 ton $\mathrm{SO}_{2} / \mathrm{yr}$} \\
\hline \multicolumn{7}{c}{}
\end{tabular}

energy and transformation industry), sector 2 (non-industrial combustion plants) and sector 3 (combustion in manufacturing industry) $(\mathrm{SNAP}=\mathrm{System}$ Nomenclature of Air Pollutants, http://www.emep.int). As there are no known major sources in that area, apart from the city itself and the harbour, both reporting mainly into different SNAP sectors, such as 7 (transport) we assumed that in this reference dataset the emission of the Nikel plant was misplaced to nearMurmansk.

Since the time trends of the emission in 2000s are uncertain and probably not significant, we used the 2003 emissions for all the modelling simulations described below.

\subsection{Modification of the emission distribution}

The correction of the emission database started from estimating the fraction of the emission attributed to Murmansk, which must be relocated to Nikel plant place. The consideration can be based on individual SNAP sectors. Assuming that the emission of SNAP sector S1 (large combustion in energy and transformation industry) is dominated by the Nikel plant, the S1 emissions in Murmansk area were moved to the Nikel plant location, leaving in the original grid cells only a small fraction, corresponding to the S1 level in the neighbouring cells. Similar logic was applied to other sectors and species that contribute to the infrastructure of a large factory (Table 4).

The new estimates are probably representative for $1990 \mathrm{~s}$ and the first half of 2000s. With the limited amount of observational data, no trend analysis seems to be feasible but the trends suggested by Boyd et al. (2009) or reported by EMEP for other parts of Russia can still be applied.

The above correction does not reposition the Nikel town emission, neither it reflects the details of the infrastructure, 
Table 4. EMEP data for 2000 (WebDab before 2006) and corrected emission data for the Nikel plant and Murmansk (unit: Tons $\mathrm{yr}^{-1}$ ). Modified dataset is suggested as reference values for 1990s-mid2000s.

\begin{tabular}{lrrrrr}
\hline \multirow{2}{*}{ Species, sector } & \multicolumn{2}{c}{ EMEP 2000 } & & \multicolumn{2}{c}{ Modified dataset } \\
\cline { 2 - 3 } \cline { 5 - 6 } & Nikel & Murmansk & & Nikel & Murmansk \\
\hline $\mathrm{SO}_{\mathrm{x}}, \mathrm{S} 1$ & 0 & 31588 & & 3158 & 0 \\
$\mathrm{SO}_{\mathrm{x}}, \mathrm{S} 2$ & 17 & 3020 & & 1509 & 1528 \\
$\mathrm{SO}_{\mathrm{x}}, \mathrm{S} 3$ & 418 & 114164 & & 76989 & 37596 \\
\hline $\mathrm{PM}_{2.5}, \mathrm{~S} 1$ & 0 & 343 & & 343 & 0 \\
$\mathrm{PM}_{2.5}, \mathrm{~S} 2$ & 12 & 2068 & & 1121 & 960 \\
$\mathrm{PM}_{2.5}, \mathrm{~S} 3$ & 10 & 2189 & & 1383 & 816 \\
$\mathrm{PM}_{2.5}, \mathrm{~S} 4$ & 0 & 9386 & & 9386 & 0 \\
$\mathrm{PM}_{2.5}, \mathrm{~S} 7$ & 6 & 435 & & 116 & 324 \\
$\mathrm{PM}_{2.5}, \mathrm{~S} 8$ & 3 & 194 & & 51 & 146 \\
$\mathrm{PM}_{2.5}, \mathrm{~S} 9$ & 3 & 118 & & 65 & 57 \\
\hline $\mathrm{PM}_{\text {coarse }}, \mathrm{S} 1$ & 0 & 398 & & 398 & 0 \\
$\mathrm{PM}_{\text {coarse }}, \mathrm{S} 2$ & 8 & 1450 & & 810 & 647 \\
$\mathrm{PM}_{\text {coarse }}, \mathrm{S} 3$ & 1 & 186 & & 117 & 70 \\
$\mathrm{PM}_{\text {coarse }}, \mathrm{S} 4$ & 0 & 3604 & & 3604 & 0 \\
$\mathrm{PM}_{\text {coarse }}, \mathrm{S} 5$ & 8 & 610 & & 167 & 451 \\
\hline
\end{tabular}

Note:

SNAP: System Nomenclature of Atmospheric Pollutants,

SNAP S1: Combustion in energy and transformation industries,

SNAP S2: Non-industrial combustion plants,

SNAP S3: Combustion in manufacturing industry,

SNAP S4: Production processes,

SNAP S5: Extraction and distribution of fossil fuels and geothermal energy,

SNAP S6: Solvents and other product use,

SNAP S7: Road transport,

SNAP S8: Other mobile sources and machinery,

SNAP S9: Waste treatment and disposal,

SNAP S10: Agriculture.

first of all, roads in the Nikel region. It is the plant emission only that has been repositioned. However, this is the biggest emission source in the Kola region.

Comparison of the emission fractions attributed to different sources (Table 1) shows, that the rearrangement of the emission pattern can be considered quite conservative, as only $\sim 40 \%$ of the $\mathrm{SO}_{2}$ emissions of the Peninsula were moved to the Nikel plant region, compared to $\sim 50 \%$ in $150 \mathrm{~km}$ resolving EMEP 1992 dataset and $\sim 70 \%$ reported by Boyd et al. (2009).

\section{Source apportionment via dispersion modelling}

In this section we present the modelling-based evidence of the problems of the present emission distribution in Kola Peninsula, demonstrate the improvements due to the above described changes and the need for further emission refinement.

\subsection{Input data and SILAM system}

\subsubsection{Observational LAPBIAT-campaign at Varrio in 2003 and other datasets}

An unequivocal indication of the missing emission source in the original EMEP inventory was obtained from the high-resolution atmospheric aerosol measurement campaign LAPBIAT carried out at Varrio, Finnish Lapland, $67^{\circ} 46^{\prime} \mathrm{N}$, $29^{\circ} 35^{\prime} \mathrm{E}$, from 28 April to 11 May 2003 (Ruuskanen et al., 2007). For the current study, we used the measurements of $\mathrm{PM}_{2.5}$ (particulate matter smaller than $2.5 \mu \mathrm{m}$ ) as an indication of industrial aerosols.

Apart from the Varrio campaign, the long-term analysis has been performed using the information from national networks of Norway (Aas et al., 2008) and Finland. For the purpose of the study, we used seven stations located close to the Nikel plant. Six of them monitor $\mathrm{SO}_{2}$ concentrations in air, one reports $\mathrm{SO}_{4}^{2-}$ in aerosol, and three report $\mathrm{SO}_{4}^{2-}$ in precipitation, which were converted to wet deposition. The deposition was chosen as a target quantity of the study because it is the cause of acidification, the primary impact of $\mathrm{SO}_{\mathrm{x}}$ in Lapland. None of the stations reported PM over sufficiently long periods, so the long-term analysis was performed for sulphur oxides.

\subsubsection{SILAM modelling system and setup}

Limited observational information, unfavourable positions of most of the stations upwind of the main emission sources (regarding the prevailing synoptic wind pattern), and contradicting input emission data preclude a direct estimation of the emission in the Nikel and Murmansk areas via full-scale data assimilation and source apportionment techniques. Alternative analyses have therefore been used.

The pollution transport simulations and simplified source apportionment have been performed with the air quality modelling system SILAM version 4, which has two - Eulerian and Lagrangian - advection-diffusion cores. The Lagrangian transport (Sofiev et al., 2006b) incorporates a high-precision iterative 3-D advection algorithm after Eerola (1990) and a Monte-Carlo random-walk representation of atmospheric diffusion. The Eulerian core, also used in the current experiment, is based on the non-diffusive advection scheme of Galperin (2000) and the adaptive vertical diffusion algorithm of Sofiev (2002). For a more detailed description we refer to Sofiev et al. (2008) and http: //silam.fmi.fi. The verification of the model has been performed within the scope of EU-GEMS project (http://www. ecmwf.int/gems) and is continued on a routine basis within the EU-MACC (http://www.gmes-atmosphere.eu). According to the outcome, an overall bias of SILAM in Europe for $\mathrm{SO}_{2}$ is within the limit of $\sim 1 \mu \mathrm{g} \mathrm{S} \mathrm{m}{ }^{-3}$.

All simulations were performed with $0.1^{\circ}$ horizontal and 6 min temporal resolution. The model vertical consisted of 
11 layers up to about $9 \mathrm{~km}$ above the surface. The modelling domain covered the area of $15^{\circ} \mathrm{E}-42^{\circ} \mathrm{E}$ and $58^{\circ} \mathrm{N}-72^{\circ} \mathrm{N}$. The contributions of Central and North-Western Europe were taken into account by nesting the domain into the SILAM European simulations, which cover the area $17^{\circ} \mathrm{W}-38^{\circ} \mathrm{E}$ and $33^{\circ} \mathrm{N}-72^{\circ} \mathrm{N}$.

The modelling was performed for 2003 and 2006 - two arbitrarily selected years for which the observational data were available. For 2003, the meteorological data were taken from the operational forecasts of the global model of European Centre of Medium Range Weather Forecast (ECMWF). The data have $0.4^{\circ}$ horizontal resolution. Simulations for 2006 were driven by the fields of the regional HIRLAM RCR system with $0.2^{\circ}$ horizontal resolution. Both datasets have 3hour time steps.

For the long term simulations the Eulerian kernel of SILAM was used. Simulations for the period of the Varrio campaign in 2003 were performed with both Lagrangian and Eulerian kernels, each driven by both ECMWF and HIRLAM meteo input. This 4-member modelling ensemble allowed more robust estimation of the dispersion patterns (compared to individual simulations) and also indicated the level of uncertainty of the results.

The input emission, depending on the specific run, was either the EMEP-original dataset for 2003 (downloaded before the 2006 change) or the same dataset with the above described corrections. For the long-term analyses the computations were made for only sulphur compounds. For the Varrio campaign, total PM concentrations were computed, consisting of primary PM, sea-salt and secondary inorganic particles (sulphates, nitrates, and ammonium).

The $\mathrm{SO}_{2} / \mathrm{SO}_{4}^{2-}$ split of the $\mathrm{SO}_{\mathrm{x}}$ emission was assumed to be $95 \% / 5 \%$ by volume for all the runs. All emission was considered in the model grid (no point sources). As insufficient amount of information is known about the Nikel stacks, no dynamic plume-rise computations were made and the emission was vertically distributed generally following the EMEP-recommended profile (Simpson et al., 2003). However, the Kola stacks are quite low: the highest one in Nikel region is about $160 \mathrm{~m}$, the tallest one in Monchegorsk is about $200 \mathrm{~m}$ (Tuovinen et al., 1993). Therefore, the EMEP vertical emission profiles for SNAP sectors S1 and S3 were lowered by $150 \mathrm{~m}$ so that in average about half of emission was injected within $200 \mathrm{~m}$ up from the stack top. The related uncertainty is discussed in Sect. 5.

\subsection{Modelling results}

\subsubsection{Is Nikel plant an active source in 2000s?}

The LAPBIAT-campaign at Varrio in 2003 provided a direct confirmation that during that time the Nikel plant was still an active source of airborne pollution. During this campaign, a few pollution episodes were observed over a generally low aerosol background of Arctic spring. The modelling attempts
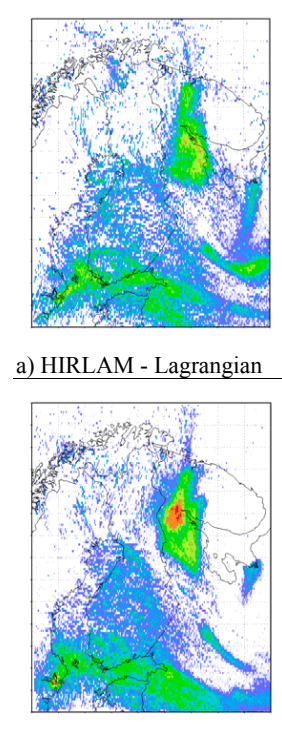

c) ECMWF - Lagrangian
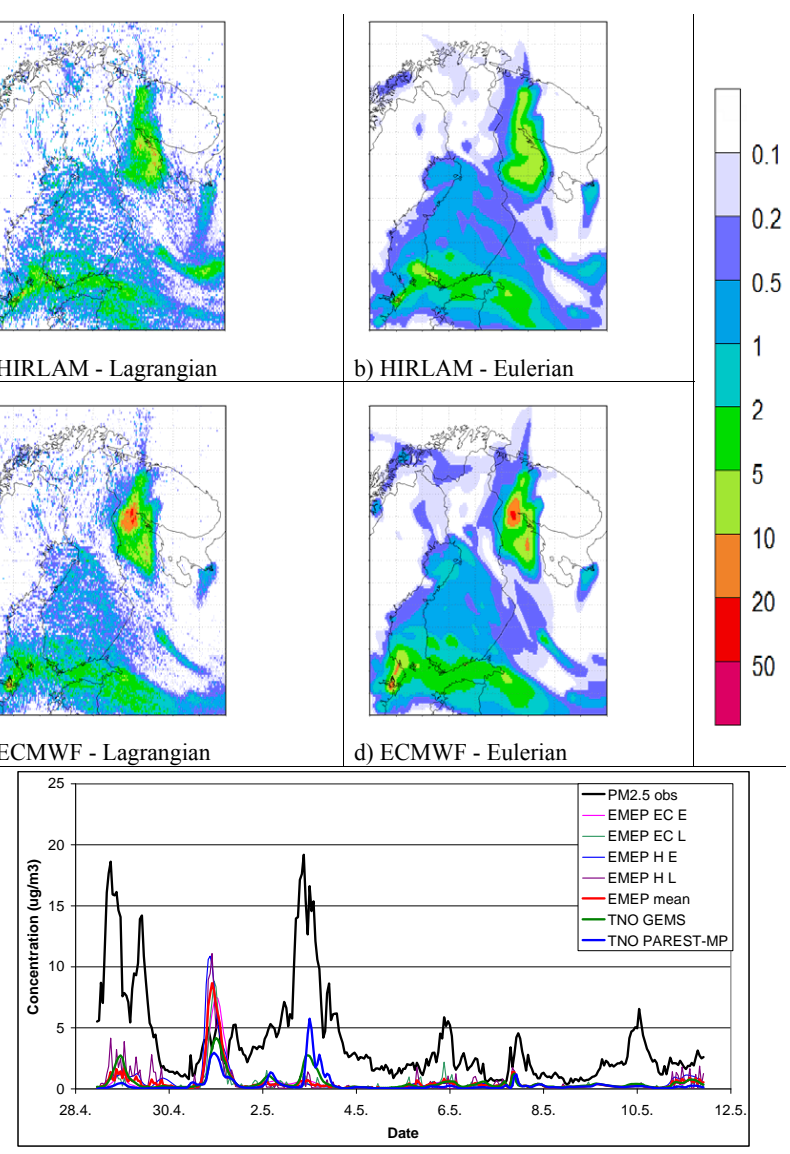

Fig. 5. Surface-level concentrations of $\mathrm{PM}_{2.5}$, 00:00 at 3 May 2003, calculated using the original EMEP emissions. Panels present the 4 members of the ensemble: (a) Lagrangian SILAM, HIRLAM meteo, (b) Eulerian SILAM, HIRLAM meteo, (c) Lagrangian SILAM, ECMWF meteo, (d) Eulerian SILAM, ECMWF meteo, (e) time series for all four computations plus Eulerian SILAM with TNOGEMS and PAREST-MEGAPOLI emissions and ECMWF meteorology, and Varrio $\mathrm{PM}_{2.5}$ observations.

to reproduce some of the strongest ones (more than 10-fold from the background level), such as the peak of 2-3 May, using the original EMEP emission data for $\mathrm{SO}_{\mathrm{x}}, \mathrm{NO}_{\mathrm{x}}, \mathrm{NH}_{\mathrm{x}}$ and primary PM, were unsuccessful - all 4 ensemble members showed neither significant concentrations near Varrio (Fig. 5) nor any probability for it: all high-concentration plumes were predicted far from the observational site. The dispersion simulations made using the TNO-GEMS and PARESTMEGAPOLI emission data reproduced the peak time (Fig. 5, lowest panel) but showed strong underestimation of its value compared to the observations.

Adjoint computations performed for the time period of the peak pointed at a small area centred around the Nikel plant (Fig. 6). Therefore, it was confirmed that at least up to 2003 the plant was an active source of anthropogenic pollution (with no indication of the reduction seen up to 2006 - see Fig. 3), which is in agreement with e.g. Boyd et al. (2009). 


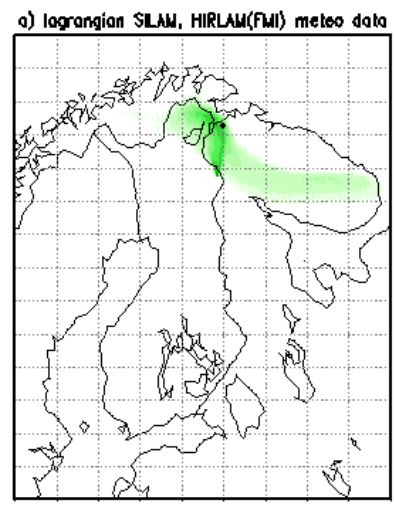

c) lagrongion SLAM, ECUUF meteo data

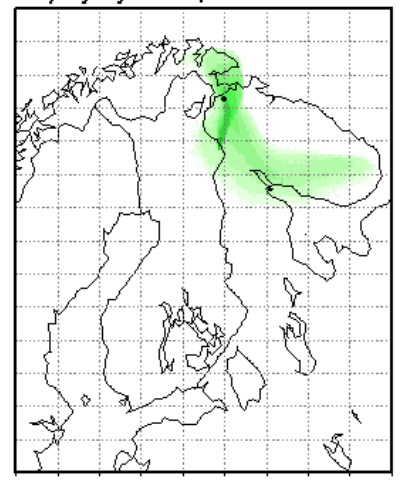

$0.01 \quad 0.03 \quad 0.1 \quad 0.3$

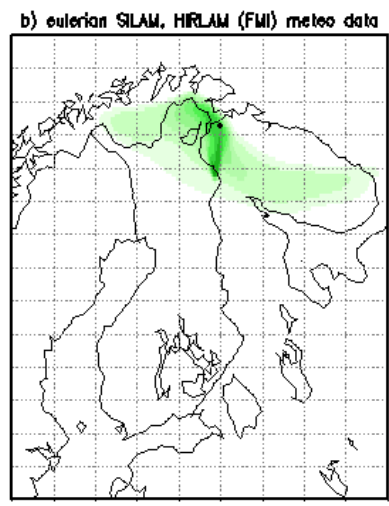

d) Eulerion SLAM, ECHuF meteo doto

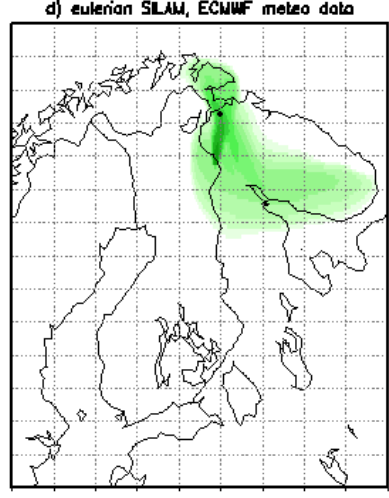

100
Fig. 6. A footprint of the highest peak of $\mathrm{PM}_{2.5}$ concentration 2-3 May 2003. Panels: (a) Lagrangian SILAM, HIRLAM meteo, (b) Eulerian SILAM, HIRLAM meteo, (c) Lagrangian SILAM, ECMWF meteo, (d) Eulerian SILAM, ECMWF meteo. Location of the Nikel plant is marked by a dot.

\subsubsection{Revised emission data of the Nikel plant: re-analysis of the Varrio campaign}

The SILAM simulations with the revised $\mathrm{PM}$ and $\mathrm{SO}_{\mathrm{x}}$ emissions $\left(\mathrm{NO}_{\mathrm{x}}\right.$ and $\mathrm{NH}_{\mathrm{x}}$ emission was not changed) produced significantly different results. In all 4 ensemble runs the high $\mathrm{PM}_{2.5}$ concentrations reached Varrio at the right time (Fig. 7). Both simulations with ECMWF meteorological input even overestimated the peak, whereas both HIRLAMdriven runs underestimated it, especially when using the Lagrangian dynamic kernel. However, the mean of the ensemble reproduces the measured peak value of total $\mathrm{PM}_{2.5}$ concentration with less than $10 \%$ error.

Analysis of Fig. 7 shows the value of the ensemble-type simulations when compared to the single-simulation assessments. Prediction of the position of narrow plumes originating from point-type sources is always uncertain and so are the absolute concentrations in the plumes. In this particular case, the variations between the model-runs exceed an order of magnitude (from less than $3 \mu \mathrm{g} \mathrm{PM}_{2.5} \mathrm{~m}^{-3}$ up to $35 \mu \mathrm{g} \mathrm{PM}_{2.5} \mathrm{~m}^{-3}$, depending on the model setup and the

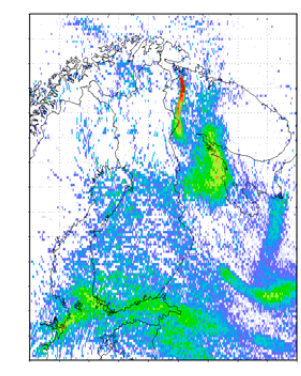

a) HIRLAM - Lagrangian

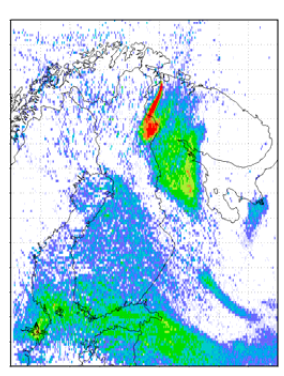

b) HIRLAM - Eulerian
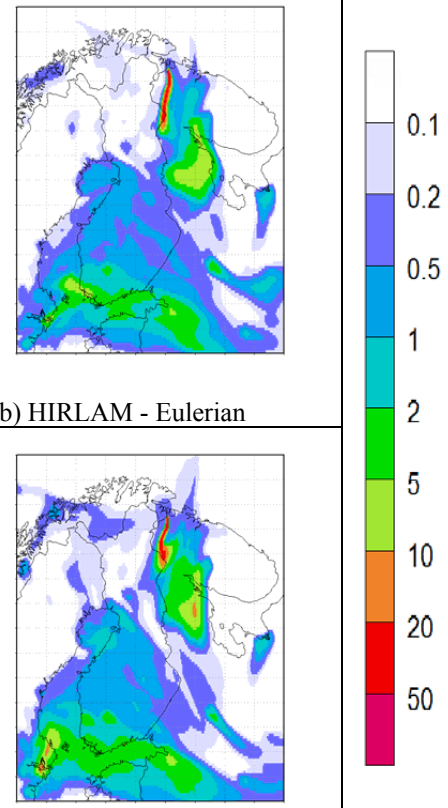

c) ECMWF - Lagrangian d) ECMWF - Eulerian

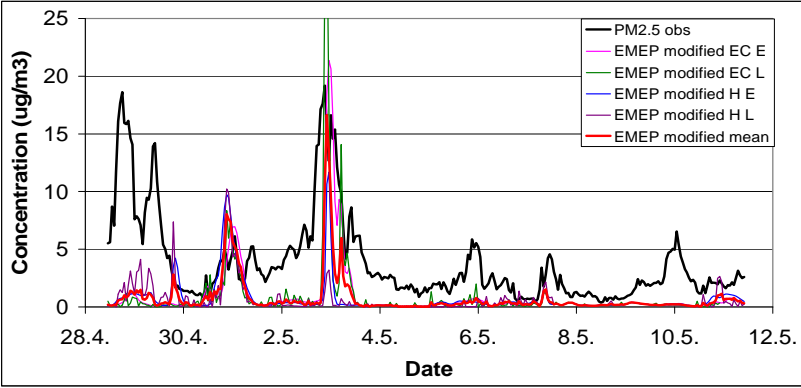

Fig. 7. Surface-level concentrations of $\mathrm{PM}_{2.5}$, 00:00 at 3 May 2003, calculated with revised EMEP emissions. Panels: (a) Lagrangian SILAM, HIRLAM meteo, (b) Eulerian SILAM, HIRLAM meteo, (c) Lagrangian SILAM, ECMWF meteo, (d) Eulerian SILAM, ECMWF meteo, (e) time series for all four computations and Varrio $\mathrm{PM}_{2.5}$ observations.

input meteorological data). The times when the polluted masses arrive and leave the observation site are within 1$2 \mathrm{~h}$ for all the simulations. As a result the ensemble both reproduces the observed peak values and points out the high uncertainty and low predictability of the case.

\subsubsection{New emission of the Nikel plant: long-term evaluation}

The above described correction of the emission distribution was used in two year-long simulations of the $\mathrm{SO}_{\mathrm{x}}$ distribution over the area. The goals of the computations were: (i) to evaluate the impact of the emission correction to the modelmeasurement comparison, (ii) to re-check the suggested regional totals, (iii) to estimate how close the new distribution is to the real emission pattern in the region, (iv) to estimate 


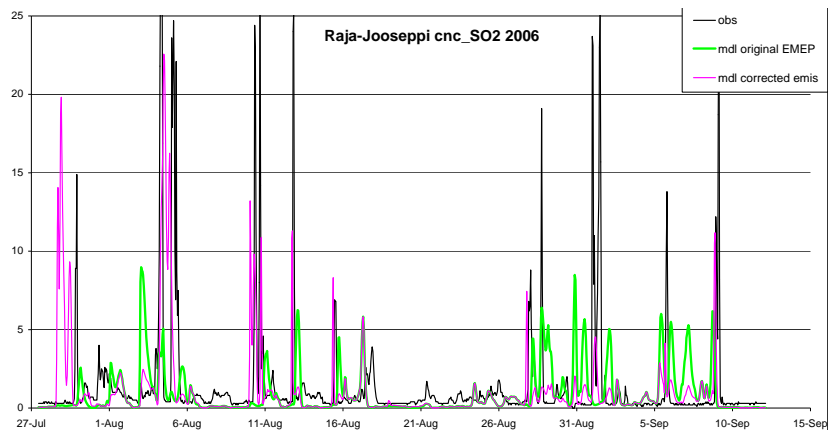

Fig. 8. Extraction of time series of modelled and measured $\mathrm{SO}_{2}$ concentrations at Raja-Jooseppi station, 2006, [ $\mu \mathrm{g} \mathrm{SO}_{2} \mathrm{~m}^{-3}$ ].

the impact of the correction onto the modelled acid deposition in the region. In order to stress the contribution of strong sources, only $\mathrm{SO}_{2}$ concentrations higher than $1 \mathrm{\mu g} \mathrm{m}^{-3}$ were taken into account in the model-measurement comparison.

In general, the new emission distribution leads to a significant improvement of the model-measurement agreement (Table 5). However, the impact is not homogeneous over the region. The influence on the predicted mean values and variability quickly decreases with the distance from the plant and depends on the site location with respect to both Murmansk and Nikel: from the 16-fold increase of the mean values (Svanvik, $9.6 \mathrm{~km}$ away from the Nikel plant) down to practically no impact at Oulanka $(345 \mathrm{~km}$ from the Nikel plant, $334 \mathrm{~km}$ from Murmansk). The concentrations are still under-estimated at all the sites, apart from the closest site to the plant (Svanvik), where some $30 \%$ of over-estimation is reported. Improvement of the temporal correlation is moderate for the concentrations (up to $\sim 45 \%$ ) but strong for wet deposition (up to 3 times). This is related to more accurate positioning of the plume from the plant, which leads to reduction of the "false alerts" and catching up the "missed peaks" in the predicted time series - see examples in Fig. 8.

From the quantile charts (Fig. 9) we can also see a substantial improvement in modelled concentrations with the revised emissions. The over-estimation of the average concentrations at Svanvik apparently comes from the moderate concentrations (from $1 \mu \mathrm{g} \mathrm{S} \mathrm{m}^{-3}$ up to $100 \mu \mathrm{g} \mathrm{m}^{-3}$ ). The frequency of episodes with $30-70 \mu \mathrm{g} \mathrm{S} \mathrm{m}{ }^{-3}$ is over-stated, while the cases with concentrations $100-250 \mu \mathrm{g} \mathrm{S} \mathrm{m}{ }^{-3}$ are under-estimated.

Quantile analysis for wet deposition is more uncertain due to weekly resolution of the observations. However, the tendency is that new source generates somewhat too high deposition near Nikel - up to 1.5 times. The apparent understatement of Svanvik deposition is due to just two extremely high observed episodes not fully reproduced by the model. It is only the farthest located site - Karasjok - where the wet deposition is still under-estimated.

To investigate whether the $\mathrm{SO}_{2}$ emission of the Nikel plant is still underestimated in the revised data, we computed the
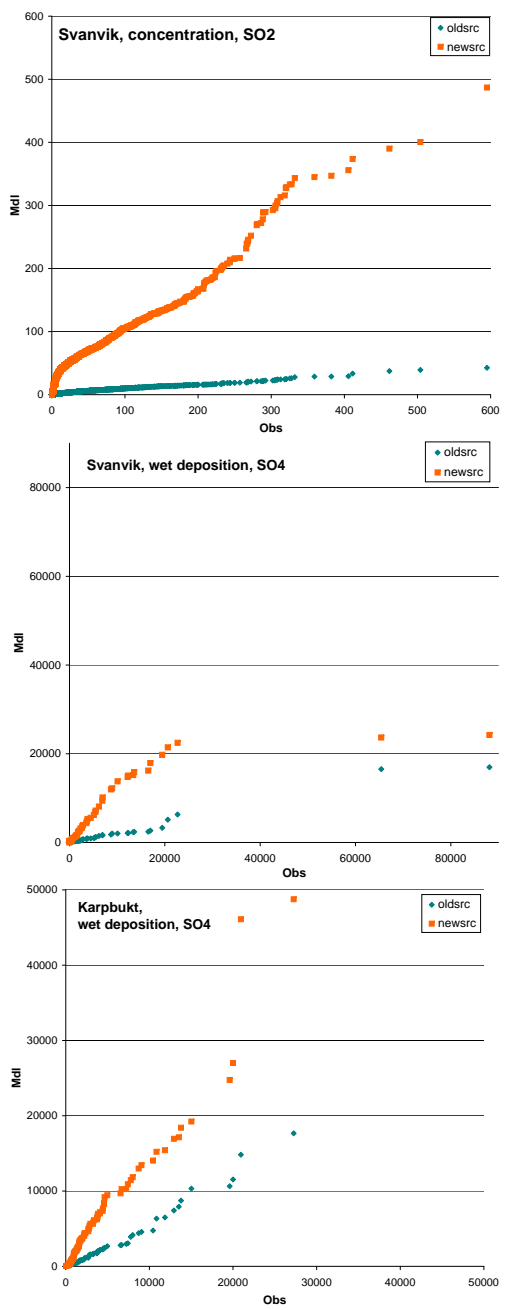

Fig. 9. Quantile charts for SILAM simulations vs. observations at the nearest sites to the Nikel plant. First panel: hourly concentration values in Svanvik [mug $\mathrm{SO}_{2} \mathrm{~m}^{-3}$ ], second and third panel: weekly wet deposition in Svanvik and Karpbukt $\left[\mu \mathrm{g} \mathrm{S} \mathrm{m}^{-2}\right.$ week $\left.^{-1}\right]$.

footprint of the differences between modelled and observed concentration peaks. The corresponding adjoint SILAM run covered the year 2006. The input for the run was compiled as a deviation of the model from the hourly concentrations reported by four monitoring sites close to Nikel. The closest site - Svanvik - was not included, as the distance from this site to the plant was less than a model grid cell size, which made its observations not representative for the current grid. For the other sites, a two-steps filtration procedure was applied to highlight only the significant problems in the model - measurement comparison. Firstly, the background concentrations in both modelled and observed time series were eliminated. Secondly, time periods with the model error less than $50 \%$ were excluded. The remaining time periods were analysed via the adjoint SILAM run. 
Table 5. Statistical scores of SILAM two-years computations at the monitoring sites. Mean over 2003 and 2006.

\begin{tabular}{|c|c|c|c|c|c|c|c|c|c|c|}
\hline \multirow[t]{2}{*}{ Station } & \multirow[t]{2}{*}{ Quantity } & \multirow{2}{*}{$\begin{array}{l}\text { Temporal } \\
\text { resolution }\end{array}$} & \multicolumn{3}{|c|}{ Average value } & \multicolumn{3}{|c|}{ Standard deviation } & \multicolumn{2}{|c|}{ Temporal correlation } \\
\hline & & & Observed & $\begin{array}{r}\text { Modelled } \\
\text { Original } \\
\text { source }\end{array}$ & $\begin{array}{r}\text { Modelled } \\
\text { Corrected } \\
\text { source }\end{array}$ & Observed & $\begin{array}{r}\text { Modelled } \\
\text { Original } \\
\text { source }\end{array}$ & $\begin{array}{c}\text { Modelled } \\
\text { Corrected } \\
\text { source }\end{array}$ & $\begin{array}{l}\text { Original } \\
\text { source }\end{array}$ & $\begin{array}{c}\text { Corrected } \\
\text { source }\end{array}$ \\
\hline Svanvik & cnc_so2 & hour & 6.34 & 0.67 & 10.93 & 25.60 & 2.31 & 26.77 & 0.33 & 0.26 \\
\hline Sammaltunturi & cnc_so 2 & hour & 0.59 & 0.12 & 0.18 & 2.10 & 0.57 & 0.81 & 0.35 & 0.41 \\
\hline Raja-jooseppi & cnc_so2 & hour & 1.26 & 0.37 & 0.57 & 3.80 & 1.27 & 2.40 & 0.24 & 0.34 \\
\hline Oulanka & cnc_so2 & hour & 0.72 & 0.46 & 0.45 & 2.11 & 1.46 & 1.35 & 0.30 & 0.33 \\
\hline Kevo & cnc_so2 & hour & 0.98 & 0.25 & 0.57 & 3.80 & 1.01 & 2.36 & 0.49 & 0.50 \\
\hline Karasjok & cnc_so2 & day & 0.78 & 0.12 & 0.20 & 2.55 & 0.51 & 0.73 & 0.35 & 0.40 \\
\hline Karasjok & cnc_so4 & day & 2.18 & 0.18 & 0.22 & 2.81 & 0.63 & 0.66 & 0.39 & 0.42 \\
\hline Karasjok & wd_so4 & day & 189.50 & 134.50 & 144.00 & 556.49 & 590.74 & 617.52 & 0.40 & 0.46 \\
\hline Svanvik & wd_so4 & week & 8875.00 & 1874.00 & 7572.00 & 16022.00 & 3458.00 & 7364.20 & 0.09 & 0.19 \\
\hline Karpbukt & wd_so4 & week & 3907.00 & 2091.00 & 6169.00 & 5138.60 & 3196.40 & 8248.70 & 0.21 & 0.65 \\
\hline
\end{tabular}

Notations:

cnc_SO2 and cnc_SO4 - concentrations of $\mathrm{SO}_{2}$ and $\mathrm{SO}_{4}$ in air or in aerosol $\left[\mu \mathrm{g} \mathrm{S} \mathrm{m}^{-3}\right]$

wd_SO4 - wet deposition of sulphates $\left[\mu \mathrm{g} \mathrm{S} \mathrm{m}^{-2}\right.$ day $\left.^{-1}\right]$ or $\left[\mu \mathrm{g} \mathrm{S} \mathrm{m}^{-2}\right.$ week $\left.^{-1}\right]$

The comparison is provided for the periods with concentrations of $\mathrm{SO}_{2}$ exceeding $1 \mu \mathrm{SO}_{2} \mathrm{~m}^{-3}$.

The overlap of the yearly-mean footprints of the significant differences ( $c_{\text {model }}-c_{\text {observed }}$ ) for the four sites (Fig. 10) shows that, apart from the areas near the sites, the footprints have a common highlighted area around the Nikel plant (circled in the map). This overlap suggests a common reason for the model under-estimation at all sites: the under-estimated emission from the Nikel plant and/or surrounding infrastructure.

\section{Discussion}

\subsection{Reliability of the revised emission pattern}

The suggested correction of the Kola emission distribution and analysis of the recent changes of the EMEP emission database are based on indirect considerations, such as the model-based source apportionment, land use analysis and heuristic analysis of the available data. All these considerations are prone to uncertainties, which in many cases are difficult to estimate. Locations of the sources are well known and easy to correct, but the actual emission rates of each of them are not. The most objective information comes from the observational sites, but in Lapland they are all located upwind from the major sources and thus require careful processing and combining with modelling for the source apportionment tasks.

The main assumption accepted as the starting point of the analysis was that the total $\mathrm{SO}_{\mathrm{x}}$ emission estimate for Kola Peninsula presented in the EMEP datasets generated before 2006 is close to the actual emission. Indeed, from the trend analysis of the observations (Fig. 3), it followed that there were no drastic changes in the emission during last two decades and the emissions of 1990s can be used as estimates for 2000s. The changes during that period were not more than a factor of 2 . It was also supported by the limited mean bias of the SILAM model and other CTMs including the EMEP model with regard to observations when run with this emission - also after 2000.

There are, however, uncertainties embedded in the approach: the model internal errors, limited representativeness of the monitoring sites, and a limited number of episodes when the impact of each of the major sources could be identified. Their crude assessment is as follows. According to Sofiev et al. (2006b), the SILAM-induced uncertainty of the mean concentrations inside the individual plumes from point sources is about 50\%. Following Galperin and Sofiev (1994), the representativeness-related uncertainty of the observed annual mean value is $\sim 20 \%$. Finally, the specific uncertainty due to sparse station network in the region located upwind from the sources can be roughly estimated from the number of episodes $N_{\text {epi }}$ when a particular site registered the plume from the plant. The standard deviation (StDev) of the mean over these episodes is proportional to $1 / \sqrt{N_{\text {epi }}}$. With typical $N_{\text {epi }} \sim 30-40$ per year, relative $\mathrm{StDev} \sim 15 \%$. This value is the lower estimate of the corresponding uncertainty. Summarising, a factor of 2 as an uncertainty of the above suggested total emission of $\mathrm{SO}_{\mathrm{x}}$ in Kola Peninsula in 2000s may be a reasonable estimate.

Uncertainties of the revised emission pattern can be summarised as follows.

The relocated emission amount was chosen to some extent arbitrarily, with only moderate justification based on SNAP sectors and surrounding background emissions. As visible from the simulation results in Fig. 8, several false $\mathrm{SO}_{2}$ concentration peaks remained in the time series modelled with 
Missed peoks footprint

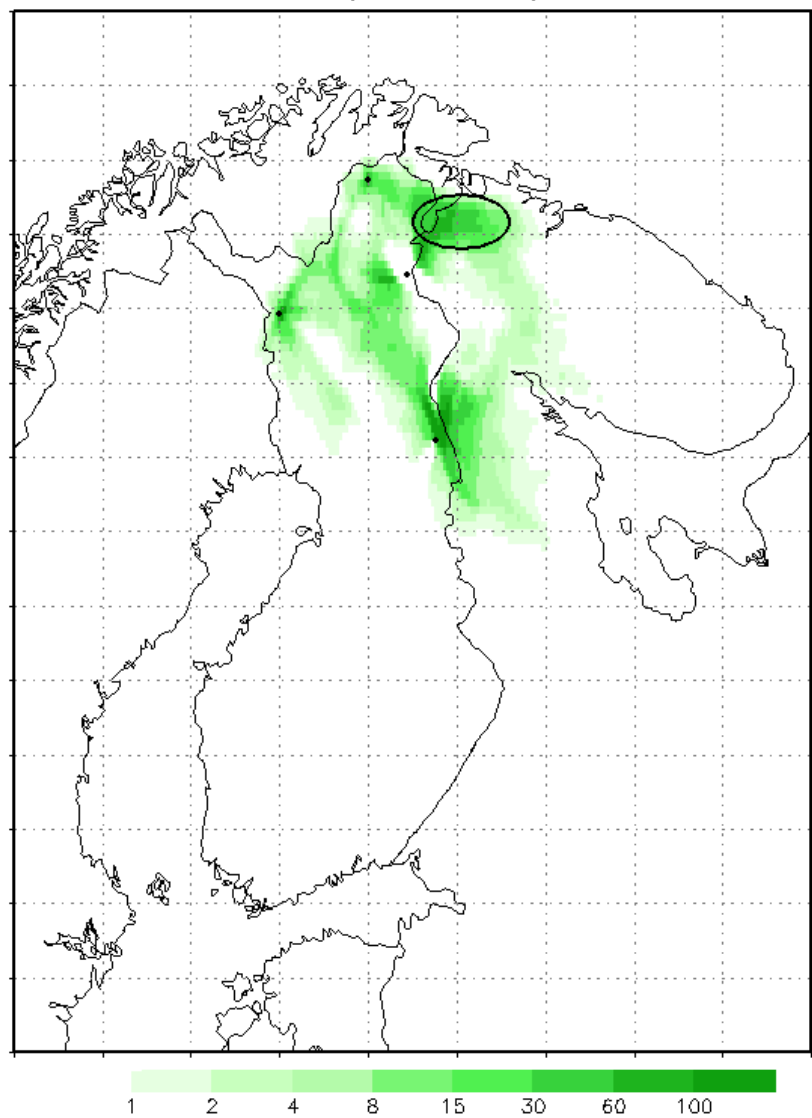

Fig. 10. Footprint of the major model-measurement differences $\left(c_{\mathrm{mdl}}-c_{\mathrm{obs}}\right)$ of $\mathrm{SO}_{2}$ concentration at monitoring sites (black dots), mean over 2006. The drawn quantity is the likelihood of the revised emission to be under-estimated. Presence of hot-spots around individual stations is an artefact originating from the low density of the observational network.

the new input. Therefore, the emission in the Murmansk area is still probably over-estimated.

Some sources of background concentrations $(<1 \mu \mathrm{g}$ $\mathrm{S} \mathrm{m}^{-3}$ ) are not included in the computations (seen as missing background in Fig. 8). These are mainly the Arctic DMS marine and ship traffic emissions outside the SILAM European modelling domain. However, DMS emission is low in the Arctic seas (Tarrasson et al., 1995; Korhonen et al., 2008), as well as the ship traffic not covered by the computation grid (http://www.ceip.at/emission-data-webdab).

The model still underestimates the $\mathrm{SO}_{2}$ peak concentrations at all stations except Svanvik by about a factor of 2 but variation is large. Wet deposition near the plant is over-stated up to 1.5 times but not farther away (Karasjok site) where it is still under-stated. Two model parameters of importance in this regard are the vertical diffusivity $\left(K_{z}\right)$ and the scavenging ratio. Computations of $K_{z}$ in stable stratification are challenging for models and recent evaluation of the SILAM
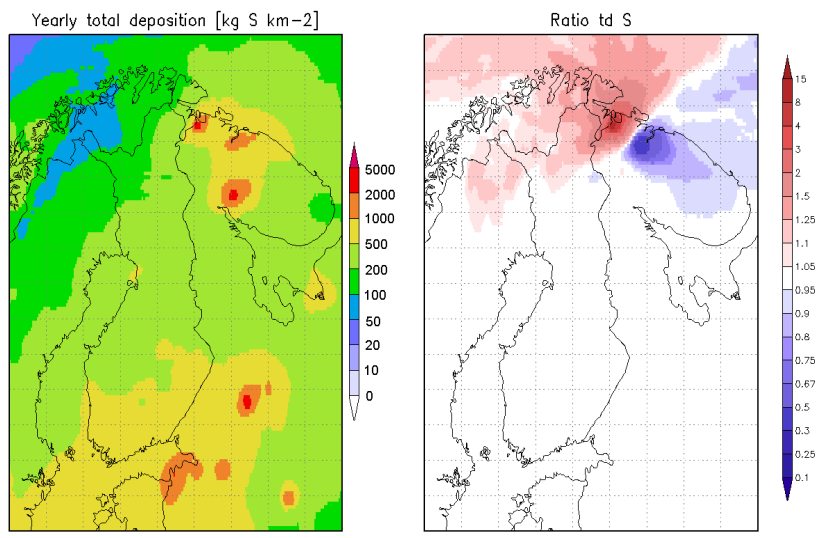

Fig. 11. Left panel: Total annual sulphur deposition after emission correction, [ $\mathrm{mg} \mathrm{S} \mathrm{m}^{-2}$ ], right panel: ratio of total sulphur depositions $D$ before and after emission correction $D_{\text {revised }} / D_{\text {original }}$, [relative units], mean over the years 2003 and 2006.

diagnostic module confirmed it (Sofiev et al., 2010). The corresponding uncertainty is inter-connected with that of the vertical dilution of the emitted plumes and affects the surface concentrations. The relocated emission of the Nikel plant is represented as a point source with the injection height approximated by the adapted EMEP profiles. However, some part of the emission probably comes from the surrounding area and infrastructure of the Nikel town. The sensitivity study based on the model computations with high (EMEPstandard profile) and low (from stack top up to $150 \mathrm{~m}$ ) injection showed that the near-source concentrations can be changed up to a few times between these two extremes, turning them e.g. at Svanvik from a factor of 2 under- to a factor of 2 over-estimation.

The $\mathrm{SO}_{\mathrm{x}}$ scavenging ratio, after Galperin (1989), decreases for high $\mathrm{SO}_{\mathrm{x}}$ concentration due to saturation of the rain droplets. However, the specific parameterization was obtained for average European conditions and may have higher uncertainties in Lapland.

Combined effect of the uncertainties in the vertical $\mathrm{SO}_{\mathrm{x}}$ distribution, scavenging efficiency, and the emission total can probably explain the above-reported differences in the model scores for surface concentrations and wet depositions. It also shows that the refinement of the Kola emission pattern via source apportionment based on generally available data has reached its limit. Further refinement has to be based on different methodology, e.g. the bottom-up inventory.

\subsection{Long-term impact of the Kola source onto northern Lapland}

The relocation of the Nikel plant emission, as shown in Fig. 11, has spatially limited and inhomogeneous but very substantial impact on the predicted sulphur deposition in Northern Lapland. These changes are particularly important due to the high sensitivity of the ecosystems in the region 
to acidifying deposition. Strong increase of the deposition (an order of magnitude) is predicted within $\sim 20 \mathrm{~km}$ from the new source location, over an almost circular area. Since substantial emission is still present in the Murmansk region, the deposition in this region reduces about 3-fold only.

\section{Conclusions}

An analysis of the different emission inventories, the observational campaigns and regular AQ monitoring in Northern Lapland, land-use, and sectoral emission split, allowed detecting problems with the total emission of Kola Peninsula and its distribution in the EMEP and other existing inventories.

A sudden 15-20-fold drop of the emission totals of $\mathrm{SO}_{\mathrm{x}}$ and PM in Kola Peninsula in 1990s, reported to EMEP since 2006, is not supported by the long term observations, which rather suggest fairly constant emission throughout 1990s and 2000 s - as in the previous versions of the database. Thus, the Kola Peninsula stays as the largest source of $\mathrm{SO}_{\mathrm{x}}$ in Northern Europe being second only to Norilsk industrial region in Northern Eurasia.

In the prior-2006 EMEP data the emission of the Nikel metallurgy plant was found to be mis-allocated to the Murmansk city region.

A refined emission for Kola Peninsula is suggested, keeping the totals at the level of pre-2006 EMEP estimates and redistributing the industrial part of the emission from the city of Murmansk to the location of the Nikel metallurgy plant.

Using forward and adjoint simulations of the SILAM system, the suggested emission correction has been verified against two years of regular $\mathrm{SO}_{2}$ monitoring data in Northern Lapland and the PM measurement campaign at Varrio in 2003. The long-term model-measurement comparison showed sharp reduction of the model under-estimation (up to slight over-estimation in the nearest vicinity to the plant) and improvement of the temporal correlation coefficient (up to 3 times).

The impact of the emission redistribution on the deposition of sulphur compounds can reach an order of magnitude but becomes small when the distance from the sources exceeds the spatial scale of the emission redistribution, i.e., the distance between the Nikel plant and Murmansk.

Further refinement of the Kola Peninsula emissions with activity-based emission assessment methods could be recommended.

It is demonstrated that a combination of several types of analyses of emission and observational data with forward and adjoint ensemble modelling allows addressing the source apportionment problems even in case of strongly limited observational data.

Acknowledgements. The research described in this paper has been partly funded by EU-GEMS (FP-6 grant SIP4-CT-2004-516099), EU-MEGAPOLI (FP/2007-2011 grant agreement no. 212520),
ESA GSE-PROMOTE, Estonian National Targeted Financing Project SF0180038s08 and grant 7005 of Estonian Science Foundation. Antoon Visschedijk is thanked for revising the point source emissions in the emission data bases. The observational data from Norwegian network were kindly provided by NILU. The Varrio measurement campaign was supported by Nordic Centre of Excellence BACCI and EU-project LAPBIAT.

Edited by: D. Simpson

\section{References}

Aas, W., Solberg, S., Berg, T., Man $\varnothing$, S., and Yttri, K. E.: Monitoring of Long-Range Transported Air and PrecipitationAtmospheric deposition, 2007, Report 1033/2008, State Pollution Control Authority, Oslo, 166 pp., 2008.

Ahonen, T., Aalto, P., Rannik, Ü., Kulmala, M., Nilsson, E. D., Palmroth, D., Ylitalo, H., and Hari, P.: Variations and vertical profiles of trace gas and aerosol concentrations and $\mathrm{CO}_{2}$ exchange in Eastern Lapland, Atmos. Environ., 31, 3351-3362, 1997.

BACC: The BACC Author team, Assessment of climate change for the Baltic Sea basin, in: Regional Climate Studies, Springer, ISBN 978-3-540-72785-9486, 2008.

Baklanov, A.: Problems of Airborne pollution in the Kola peninsula, EURASAP: European Association for the Science of Air Pollution, Newsletter, 23, 5-11, 1994.

Barletta, B., Meinardi, S., Simpson, I. J., Atlas, E. L., Beyersdorf, A. J., Baker, A. K., Blake, N. J., Yang, M., Midyett, J. R., Novak, B. J., McKeachie, R. J., Fuelberg, H. E., Sachse, G. W., Avery, M. A., Campos, T., Weinheimer, A. J., Rowland, F. S., and Blake, D. R.: Characterization of volatile organic compounds (VOCs) in Asian and north American pollution plumes during INTEX-B: identification of specific Chinese air mass tracers, Atmos. Chem. Phys., 9, 5371-5388, doi:10.5194/acp-9-5371-2009, 2009.

Bartnicki, J., Gusev, A., Barret, K., and Simpson, D.: Atmospheric supply of nitrogen, lead, cadmium, mercury and lindane to the Baltic Sea in the period 1996-2000, Joint EMEP cetres report for HELCOM 2002, EMEP, http://www.emep.int, last access: 24 June 2010, 2002.

Bartnicki, J., Gusev, A., Berg, T., and Fagerli, H.: Atmospheric Supply of Nitrogen, Lead, Cadmium, Mercury and Lindane to the Baltic Sea in 2002, EMEP/MSC-W technical report 3/2004, 2004.

Bartnicki, J., Gusev, A., Aas, W., and Fagerli, H.: Atmospheric Supply of Nitrogen, Lead, Cadmium, Mercury and Dioxines/Furanes to the Baltic Sea in 2004, EMEP/MSC-W technical report 3/2006, Oslo, September 2006, ISSN 0332-9879, 2006.

Bergamaschi, P., Krol, M., Dentener, F., Vermeulen, A., Meinhardt, F., Graul, R., Ramonet, M., Peters, W., and Dlugokencky, E. J.: Inverse modelling of national and European $\mathrm{CH}_{4}$ emissions using the atmospheric zoom model TM5, Atmos. Chem. Phys., 5, 2431-2460, doi:10.5194/acp-5-2431-2005, 2005.

Berglen, T. F., Sivertsen, B., and Arnesen, K.: Air quality monitoring in the border areas of Norway and Russia progress report April 2007-March 2008, Statlig program for forurensningsovervåking, Rapport 1037/2008, TA-2445/2008, ISBN 978-82-425-2032-6, NILU, 76 pp., 2008. 
Bocquet, M.: Reconstruction of an atmospheric tracer source using the principle of maximum entropy, I: Applications, Q. J. Roy. Meteor. Soc., 131, 2209-2223, 2005a.

Bocquet, M.: Reconstruction of an atmospheric tracer source using the principle of maximum entropy, I: Theory, Q. J. Roy. Meteor. Soc., 131, 2191-2208, 2005b.

Boyd, R., Barnes, S.-J., De Caritat, P., Chekushin, V. A., Melezhik, V. A., Reimann, C., and Zientek, M. L.: Emissions from the copper-nickel industry on the Kola Peninsula and at Norilsk, Russia, Atmosph. Environ., 43, 1474-1480, 2009.

Chang, M. I., Hartley, D. E., Cardelino, C., Haas-Laursen, D., and Chang, W. L.: On using inverse methods for resolving emissions with large spatial inhomogenities, J. Geophys. Res., 102, 1602316036, 1997.

Committee: Report of Komitet ekologii i prirodnih resursov Murmanskoi oblasti, Ministerstvo ohrani okrugaushei sredi prirodnih resursov rossiiskoi federatsii, Sostojanie I ohrana okrugaushei prirodnoi sredi Murmanskoi oblasti v 1994, 1995.

Delle Monache, L. and Stull, R. B.: An ensemble air-quality forecast over western Europe during an ozone episode, Atmos. Environ., 37, 3469-3474, 2003.

Delle Monache, L., Hacker, J. P., Zhou, Y., Deng, X., and Stull, R. B.: Probabilistic aspects of meteorological and ozone regional ensemble forecasts, J. Geophys. Res., 111, D24307, doi:10.1029/2005JD006917, 2006.

Denier van der Gon, H. A. C., Visschedijk, A., van der Brugh, H., and Dröge, R.: A high resolution European emission data base for the year 2005, A contribution to UBA-Projekt PAREST Particle Reductions Strategies, TNO report, Utrecht, The Netherlands, in preparation, 2010.

Eerola, K.: Experimentation with a three-dimensional trajectory model, FMI Meteorological Publication 15, 33pp., 1990.

Elbern, H. and Schmidt, H.: A four dimensional variational chemistry data assimilation scheme for eulerian chemistry transport modeling, J. Geophys. Res., 104, 18583-18598, 1999.

Elbern, H., Schmidt, H., and Ebel, A.: Lagrangian four-dimensional variational data assimilation of chemical species, J. Geophys. Res., 102, 15967-15985, 1997.

Elbern, H., Strunk, A., Schmidt, H., and Talagrand, O.: Emission rate and chemical state estimation by 4-dimensional variational inversion, Atmos. Chem. Phys., 7, 3749-3769, doi:10.5194/acp7-3749-2007, 2007.

EMEP: Transboundary acidification and eutrophicaltion in Europe, EMEP summary report CCC \& MSC-W 1999, EMEP report 1/1999, 70 pp., 1999.

EMEP: Transboundary acidification and eutrophicaltion in Europe, EMEP summary report CCC \& MSC-W 2000, EMEP report 1/2000, 264 pp., 2000.

EMEP: Transboundary Acidification, Eutrophication and Ground Level Ozone in Europe from 1990 to 2004 in support for the review of the Gothenburg Protocol, EMEP status report 1/2006, ISSN 1504-6109, 93 pp., 2006.

EMEP: Transboundary Acidification, Eutrophication and Ground Level Ozone in Europe in 2005, EMEP status report 1/2007, ISSN 1504-6109, 147 pp., 2007.

EMEP: Transboundary Acidification, Eutrophication and Ground Level Ozone in Europe in 2006, EMEP status report 1/2008, ISSN 1504-6109, 220 pp., 2008.
EMEP: Transboundary Acidification, Eutrophication and Ground Level Ozone in Europe in 2007, EMEP status report 1/2009, ISSN 1504-6109, 169pp., 2009.

Erdman, L., Galperin, M., Subbotin, S., Sofiev, M., and Afinogenova, O.: Modelling experience of the Arctic pollution with sulphur and nitrogen compounds, heavy metals from sources of the Northern Hemisphere, EMEP/MSC-E note 1/94, Moscow, February 1994, p. 40, 1994.

Galmarini, S., Bianconi, R., Klug, W., Mikkelsen, T., Addis, R., Andronopoulos, S., Astrup, P., Baklanov, A., Bartniki, J., Bartzis, J. C., Bellasio, R., Bompay, F., Buckley, R., Bouzom, M., Champion, H., D’Amours, R., Davakis, E., Eleveld, H., Geertsema, G. T., Glaab, H., Kollax, M., Ilvonen, M., Manning, A., Pechinger, U., Persson, C., Polreich, E., Potemski, S., Prodanova, M., Saltbones, J., Slaper, H., Sofiev, M. A., Syrakov, D., Sùrensen, J. H., Van der Auwera, L., Valkama, I., and Zelazny, R.: Can the confidence in long-range atmospheric transport models be increased? The pan-European experience of ENSEMBLE, Radiat. Prot. Dosim., 109, 1-2, 19-24, doi:10.1093/rpd/nch261, 2004a.

Galmarini, S., Bianconi, R., Klug, W., Mikkelsen, T., Addis, R., Andronopoulos, S., Astrup, P., Baklanov, A., Bartniki, J., Bartzis, J. C., Bellasio, R., Bompay, F., Buckley, R., Bouzom, M., Champion, H., D’Amours, R., Davakis, E., Eleveld, H., Geertsema, G. T., Glaab, H., Kollax, M., Ilvonen, M., Manning, A., Pechinger, U., Persson, C., Polreich, E., Potempski, S., Prodanova, M., Saltbones, J., Slaper, H., Sofiev, M. A., Syrakov, D., Sørensen, J. H., Van der Auwera, L., Valkama, I., and Zelazny, R.: Ensemble dispersion forecasting - Part I: concept, approach and indicators, Atmos. Environ., 38(28), 4607-4617, 2004b.

Galmarini, S., Bianconi, R., Addis, R., Andronopoulos, S., Astrup, P., Bartzis, J. C., Bellasio, R., Buckley, R., Champion, H., Chino, M., D’Amours, R., Davakis, E., Eleveld, H., Glaab, H., Manning, A., Mikkelsen, T., Pechinger, U., Polreich, E., Prodanova, M., Slaper, H., Syrakov, D., Terada, H., and Van der Auwera, L.: Ensemble dispersion forecasting - Part II: application and evaluation, Atmos. Environ., 38(28), 4619-4632, 2004c.

Galperin, M.: The approaches to correct computation of airborne pollution advection, in: Problems of ecological Monitoring and Ecosystem Modelling, Gidrometeoizdat, 54-68, 2000.

Galperin, M. and Sofiev, M.: Robustness of methods for comparison of measured and calculated data, MSC-E Report 2/94, Moscow, February 1994, p. 25, 1994.

Galperin, M. and Sofiev, M.: The long-range transport of ammonia and ammonium in the Northern Hemisphere, Atmos. Environ., 32(3), 373-380, 1998.

Galperin, M., Dedkova, I., Sofiev, M., and Perelmuter, Y.: The approach to integrated assessment modelling developed by MSC-E, MSC-E Report 1/94, Moscow, February 1994, p. 34, 1994.

Hagen, L. O., Sivertsen, B., and Arnesen, K.: Grenseområdene i Norge og Russland Luft- og nedbørkvalitet, April 2005Mars 2006, NILU Rep. OR 69/2006, Norwegian Institute of Air Research, 2002.

Heo, J.-B., Hopke, P. K., and Yi, S.-M.: Source apportionment of $\mathrm{PM}_{2.5}$ in Seoul, Korea, Atmos. Chem. Phys., 9, 4957-4971, doi:10.5194/acp-9-4957-2009, 2009.

Hongisto, M., Sofiev, M., and Joffre, S.: Hilatar, a limited area simulation model of acid contaminants: II. Model verification and long-tern simulation results, Atmos. Environ., 37, 1549-1560, 2003. 
Issartel, J.-P.: Emergence of a tracer source from air concentration measurements, a new strategy for linear assimilation, Atmos. Chem. Phys., 5, 249-273, doi:10.5194/acp-5-249-2005, 2005.

Issartel, J.-P. and Baverel, J.: Inverse transport for the verification of the Comprehensive Nuclear Test Ban Treaty, Atmos. Chem. Phys., 3, 475-486, doi:10.5194/acp-3-475-2003, 2003.

Korhonen, H., Carslaw, K. C., Spracklen, D. V. Mann, G. W., and Woodhouse, M. T.: Influence of oceanic dimethyl sulphide emissions on cloud condensation nuclei concentrations and seasonality over the remote Southern Hemisphere oceans: A global model study, J. Geophys. Res., 113, D15204, doi:10.1029/2007JD009718, 2008.

Kulmala, M., Rannik, Ü., Pirjola, L., Dal Maso, M., Karimäki, J., Asmi, A., Jäppinen, A., Karhu, V., Korhonen, H., Malvikko, S.-P., Raittila, J., Romakkaniemi, S., Suni, T., Yli-Koivisto, S., Paatero, J., Hari, P. and Vesala, T.: Characterization of atmospheric trace gas and aerosol concentrations at forest sites in southern and northern Finland using back trajectories, Boreal Environ. Res., 5, 315-336, 2000.

Kuparinen, A., Markkanen, T., Riikonen, H., and Vesala, T.: Modeling air-mediated dispersal of spores, pollen and seeds in forested areas, Ecol. Model., 208, 177-188, 2007a.

Loosmore, J., Nitao, J., Sugiyama, G. A., and Vogt, P. J.: Bayesian inference and Markov Chain Monte Caro sampling to reconstruct a contaminant source at continental scale, J. Appl. Meteorol. Clim., 47(10), 2600-2613, 2007.

Mallet, V. and Sportisse, B.: Ensemble-based air quality forecasts:A multimodel approach applied to ozone, J. Geophys. Res., 111, D18302, doi:10.1029/2005JD006675, 2006.

Pagowski, M. and Grell, G. A.: Ensemble-based ozone forecasts: Skill and economic value, J. Geophys. Res., 111, D23S30, doi:10.1029/2006JD007124, 2006.

Potempski, S., Galmarini, S., Addis, R., Astrup, P., Bader, S., Bellasio, R., Bianconi, R., Bonnardot, F., Buckley, R., D’Amours, R., van Dijk, A., Geertsema, G., Jones, A., Kaufmann, P., Pechinger, U., Perssonm, C., Polreich, E., Prodanova, M., Robertsonm, L., Sørensen, J., and Syrakov, D.: Multi-model ensemble analysis of the ETEX-2 experiment, Atmos. Environ., 42, 7250-7265, 2008.

Rannik, Ü., Markkanen, T., Raittila, J., Hari, P., and Vesala, T.: Turbulence statistics inside and over forest: influence on footprint prediction, Bound.-Lay. Meteorol., 109, 163-189, 2003.

Riccio, A., Giunta, G., and Galmarini, S.: Seeking for the rational basis of the Median Model: the optimal combination of multimodel ensemble results, Atmos. Chem. Phys., 7, 6085-6098, doi:10.5194/acp-7-6085-2007, 2007.

Ruuskanen, T. M., Reissell, A., Keronen, P., Aalto, P. P., Laakso, L., Grönholm, T., Hari, P., and Kulmala, M.: Atmospheric trace gas and aerosol particle concentration measurements in Eastern Lapland, Finland 1992-2001, Boreal Environ. Res., 8, 335-349, 2003.

Ruuskanen, T. M., Kaasik, M., Aalto, P. P., Hõrrak, U., Vana, M., Mårtensson, M., Yoon, Y. J., Keronen, P., Mordas, G., Ceburnis, D., Nilsson, E. D., O’Dowd, C., Noppel, M., Alliksaar, T., Ivask, J., Sofiev, M., Prank, M., and Kulmala, M.: Concentrations and fluxes of aerosol particles during the LAPBIAT measurement campaign at Värriö field station, Atmos. Chem. Phys., 7, 3683-3700, doi:10.5194/acp-7-3683-2007, 2007.
Saarikoski, S., Sillanpää, M., Sofiev, M., Timonen, H., Saarnio, K., Teinilä, K., Karppinen, A., Kukkonen, J., and Hillamo, R.: Chemical composition of aerosols during a major biomass burning episode over northern Europe in spring 2006: experimental and modelling assessments, Atmos. Environ., 41, 3577-3589, 2007.

Simpson, D., Fagerli, H., Jonson, J. E., Tsyro, S., Wind, P., and Tuovinen, J.-P.: Transboundary acidification and eutrophication and ground level ozone in Europe: Unified EMEP Model Description, EMEP Status Report 1/2003, Part I, EMEP/MSC-W Report, The Norwegian Meteorological Institute, Oslo, Norway, 104 pp., 2003.

Skjøth, A. C., Sommerw, J., Stachz, A., Smithz, M., and Brandt, J.: The long-range transport of birch (Betula) pollen from Poland and Germany causes significant pre-season concentrations in Denmark, Clin. Exp. Allergy, 37, 1204-1212, 2007.

Sofiev, M.: A model for the evaluation of long-term airborne pollution transport at regional and continental scales, Atmos. Environ., 34(5), 2481-2493, 2000.

Sofiev, M.: Extended resistance analogy for construction of the vertical diffusion scheme for dispersion models, J. Geophys. Res.Atmos., 107(D12), 4159, doi:10.1029/2001JD001233, 2002.

Sofiev, M., Gusev, L., and Strijkina, I.: Results of MSC-East current model calibration with measurement of $\mathrm{SO}_{\mathrm{X}}, \mathrm{NO}_{\mathrm{X}}, \mathrm{NH}_{\mathrm{X}}$ 198793, MSC-E Report 4/94, March 1994, p. 125, 1994.

Sofiev, M., Gusev, A., and Afinogenova, O.: Atmospheric transport of acid compounds in the Northern Hemisphere for 1991-1994, MSC-E Report 8/95, Moscow, June 1995, p. 44, 1995.

Sofiev, M., Maslyaev, A., and Gusev, A.: Heavy metal model intercomparison. Methodology and results for $\mathrm{Pb}$ in 1990, MSC-E Report 2/96, Moscow, March 1996, p. 108, 1996.

Sofiev, M., Kaasik, M., and Hongisto, M.: Distribution of alcaline particles over the Baltic Sea basin, Water Air Soil Poll., 146, 211-223, 2003.

Sofiev, M., Siljamo, P., Ranta, H., and Rantio-Lehtimäki, A.: Towards numerical forecasting of long-range air transport of birch pollen: theoretical considerations and a feasibility study, Int. J. Biometeorol., 50, 392-402, 2006a.

Sofiev, M., Siljamo, P., Valkama, I., Ilvonen, M., and Kukkonen, J.: A dispersion modelling system SILAM and its evaluation against ETEX data, Atmos. Environ., 40, 674-685, doi:10.1016/j.atmosenv.2005.09.069, 2006b.

Sofiev, M., Galperin, M., and Genikhovich, E.: Construction and evaluation of Eulerian dynamic core for the air quality and emergency modeling system SILAM, in: NATO Science for piece and security Serties C: Environmental Security, Air pollution modelling and its application, XIX, edited by: Borrego, C. and Miranda, A. I., Springer, 699-701, 2008.

Sofiev, M., Genikhovich, E., Keronen, P., and Vesala, T.: Diagnosing the surface layer parameters for dispersion models within the meteorological-to-dispersion modeling interface, J. Appl. Meteorol. Clim., 221-233, doi:10.1175/2009JAMC2210.1, 2010.

Sogacheva, L., Dal Maso, M., Kerminen, V.-M., and Kulmala, M.: Probability of nucleation events and aerosol particle concentration in different air mass types arriving at Hyytiälä, Southern Finland, based on back trajectory analysis, Boreal Environ. Res., 10, 479-491, 2005. 
Sogacheva, L., Hamed, A., Facchini, M. C., Kulmala, M., and Laaksonen, A.: Relation of air mass history to nucleation events in Po Valley, Italy, using back trajectories analysis, Atmos. Chem. Phys., 7, 839-853, doi:10.5194/acp-7-839-2007, 2007.

Tarrasson, L., Turner, S., and Floisand, I.: Estimation of seasonal dimethyl sulphide fluxes over the North Atlantic Ocean and their contribution to European pollution levels, J. Geophys. Res., 100(D6), 11623-11639, 1995.

Thomson, L. C. Hirst, B., Gibson, J., Gillespie, S., Jonathan, P., Skeldon, K. D., and Padgett, M. J.: An improved algorithm for locating a gas source using inverse methods, Atmos. Environ., 41, 1128-1134, 2007.

Tuovinen, J.-P., Laurila, T., Lättilä, H., Ryaboshapko, A., Brukhanov, P., and Korolev, S.: Impact of the sulphur dioxide sources in the Kola Peninsula on air quality in northernmost Europe, Atmos. Environ., 27(9), 1379-1395, 1993.

UNECE: Present state of emission data, ECE/EB.AIR/97, 2009.

Vestreng, V., Adams, M., and Goodwin, J.: Inventory Review 2004, Emission data reported to CLRTAP and the NEC Directive, EMEP/EEA Joint Review Report, EMEP/MSC-W Note 1, Lillestrom, July 2004, 120 pp., 2004.
Virkkula, A., Teinilä, K., Hillamo, R., and Stohl, A.: A decade of trace gas measurements using DOAS in Finnish Lapland, Boreal Environ. Res., 8, 351-363, 2003.

Visschedijk, A. J. H., Zandveld, P. Y. J., and Denier van der Gon, H. A. C. A.: High resolution gridded European emission database for the EU integrate project GEMS, TNO-report 2007A-R0233/B, 2007.

Zientek, M. L., Likhachev, A. P., Kunilov, V. E., Barnes, S.-J., Meier, A. L., Carlson, R. R., Briggs, P. H., Fries, T. L., Adrian, B. M., Lightfoot, P. C., and Naldrett, A. J.: Cumulus processes and the composition of magmatic ore deposits: examples from the Talnakh district, Russia, in: Proceedings of the Sudbury Noril'sk Symposium, Ontario Geological Survey Special Publication, 5, 373-392, 1994.

Zlatev, Z., Bergstrom, R., Brandt, J., Hongisto, M., Johnson, J.E., Langner, J., and Sofiev, M.: Studying sensitivity of air pollution levels caused by variations of different key parameters, TemaNord 2001:569, Nordic Council of Ministers, Copenhagen 2001, 50 pp., 2002. 